Article

\title{
The Petyayan-Vara Carbonatite-Hosted Rare Earth Deposit (Vuoriyarvi, NW Russia): Mineralogy and Geochemistry
}

\author{
Evgeniy Kozlov ${ }^{1, * \mathbb{C}}$, Ekaterina Fomina ${ }^{1} \mathbb{C}$, Mikhail Sidorov ${ }^{1}$, Vladimir Shilovskikh ${ }^{2,3} \mathbb{C}^{\text {, }}$ \\ Vladimir Bocharov ${ }^{2}{ }^{\mathbb{D}}$, Alexey Chernyavsky ${ }^{1}$ and Miłosz Huber ${ }^{4}$ \\ 1 Geological Institute, Kola Science Centre, Russian Academy of Sciences, 14, Fersmana Street, \\ 184209 Apatity, Russia; fomina_e.n@mail.ru (E.F.); sidorov@geoksc.apatity.ru (M.S.); \\ chernyavsky@geoksc.apatity.ru (A.C.) \\ 2 Research Center «GEOMODEL», St. Petersburg State University, 1, Ulyanovskaya street, \\ 198504 Saint-Petersburg, Russia; vova_bel@mail.ru (V.S.); bocharov@molsp.phys.spbu.ru (V.B.) \\ 3 Institute of Mineralogy, Ural Branch of the Russian Academy of Sciences, 456317 Miass, Russia \\ 4 Department of Geology and Lithosphere Conservation, Institute of Earth Sciences, Maria Curie-Skłodowska \\ University, 2CD, al. Kraśnicka, 20-718 Lublin, Poland; mhuber@poczta.umcs.lublin.pl \\ * Correspondence: kozlov_e.n@mail.ru; Tel.: +7-953-758-7632
}

Received: 12 December 2019; Accepted: 15 January 2020; Published: 17 January 2020

\begin{abstract}
The Vuoriyarvi Devonian carbonatite-ijolite-pyroxenite-olivinite complex comprises several carbonatite fields: Neske Vara, Tukhta-Vara, and Petyayan-Vara. The most common carbonatites in the Tukhta-Vara and Neske-Vara fields are calciocarbonatites, which host several P, Fe, $\mathrm{Nb}$, and Ta deposits. This paper focuses on the Petyayan-Vara field, in which the primary magmatic carbonatites are magnesian. The least altered magnesiocarbonatites are composed of dolomite with burbankite and are rich in REE (up to $2.0 \mathrm{wt}$. \%), Sr (up to $1.2 \mathrm{wt}$. \%), and Ba (up to $0.8 \mathrm{wt}$ \%). These carbonatites underwent several stages of metasomatism. Each metasomatic event produced a new rock type with specific mineralization. The introduction of $\mathrm{K}, \mathrm{Si}, \mathrm{Al}, \mathrm{Fe}, \mathrm{Ti}$, and $\mathrm{Nb}$ by a F-rich fluid (or fluid-saturated melt) resulted in the formation of high-Ti magnesiocarbonatites and silicocarbonatites, composed of dolomite, microcline, Ti-rich phlogopite, and Fe-Ti oxides. Alteration by a phosphate-fluoride fluid caused the crystallization of apatite in the carbonatites. A sulfate-rich $\mathrm{Ba}-\mathrm{Sr}$-rare-earth elements (REE) fluid (probably brine-melt) promoted the massive precipitation of ancylite and baryte and, to a lesser extent, strontianite, bastnäsite, and synchysite. Varieties of carbonatite that contain the highest concentrations of REE are ancylite-dominant. The influence of sulfate-rich Ba-Sr-REE fluid on the apatite-bearing rocks resulted in the dissolution and reprecipitation of apatite in situ. The newly formed apatite generation is rich in HREE, Sr, and S. During late-stage transformations, breccias of magnesiocarbonatites with quartz-bastnäsite matrixes were formed. Simultaneously, strontianite, quartz, calcite, monazite, HREE-rich thorite, and Fe-hydroxides were deposited. Breccias with quartz-bastnäsite matrix are poorer in REE (up to $4.5 \mathrm{wt}$. \% total REE) than the ancylite-dominant rocks (up to $11 \mathrm{wt}$. \% total REE).
\end{abstract}

Keywords: alkaline-ultrabasic complexes; carbonatites; rare-earth elements; ancylite; bastnäsite; metasomatism; Vuoriyarvi; Kola alkaline province

\section{Introduction}

Rare-earth elements (REEs) are widely viewed as critical metals due to their extensive use in modern and "green" technologies [1,2]. Carbonatites, i.e., igneous rocks composed of more than 50 vol. \% primary magmatic carbonates of $\mathrm{Ca}, \mathrm{Mg}$, Fe, and $\mathrm{Mn}$ and less than 20 wt. \% of $\mathrm{SiO}_{2}$ [3], 
account for more than $50 \%$ of the global resources of REE [4]. Therefore, rare earth carbonatites are a major focus of critical metal research. Over the past five years, several dozens of papers have been published on the subject of rare earth carbonatites (RE carbonatites) in Angola [5,6], Australia [7-9], Brazil [10,11], Canada [12-17], China [18-37], Finland [38], India [39-42], Italy [43,44], Malawi [45-51], Mongolia [52,53], Namibia [54-56], New Zealand [57], Norway [58], Russia [59-64], South Africa [65,66], Tanzania [67], the USA [68-72], and Vietnam [73], as well as reviews (e.g., [74-76]). Importantly, the weight percentage levels of REEs required for an economic deposit commonly occur in magnesioand iron-rich carbonatite dykes and veins (i.e., in the latest and most highly evolved parts of a carbonatite intrusion) [2,77]. In these rocks, REE accumulation is assumed to be controlled by fluid activity $[2,45,57,62,68,77-82]$.

Carbonatites of the Petyayan-Vara field (Vuoriyarvi massif, northwest Russia) are magnesiocarbonatites with ancylite as their predominant REE mineral. These carbonatites were discovered in the early 1960s, during the exploration of glimmerites, and have not been thoroughly studied since [83]. In this work, we present the first mineralogical and geochemical data for carbonatites of the Petyayan-Vara field.

\section{Geological Setting}

The Vuoriyarvi alkaline-ultrabasic carbonatite massif (Kola region, Russia) is one of more than 20 alkaline complexes of the Devonian Kola Alkaline Province [84]. The geological structure of this massif is complex due to its multiphase nature. The Vuoriyarvi massif was formed by several pulses of geochemically contrasting magmas. These magmas produced (in the sequence of formation) olivinites, pyroxenites, foidolites, nepheline syenites, and carbonatites (Figure 1). Carbonatites are widespread in the southeastern part of the massif and form rod-like bodies, stockworks, and dykes of varying sizes (up to several hundred meters in length) near the Tukhta-Vara and Neske-Vara hills. Most are calciocarbonatites with ore minerals, including apatite, magnetite, and pyrochlore [83]. Traditionally, the Vuoriyarvi massif has been regarded as a large niobium deposit [85].

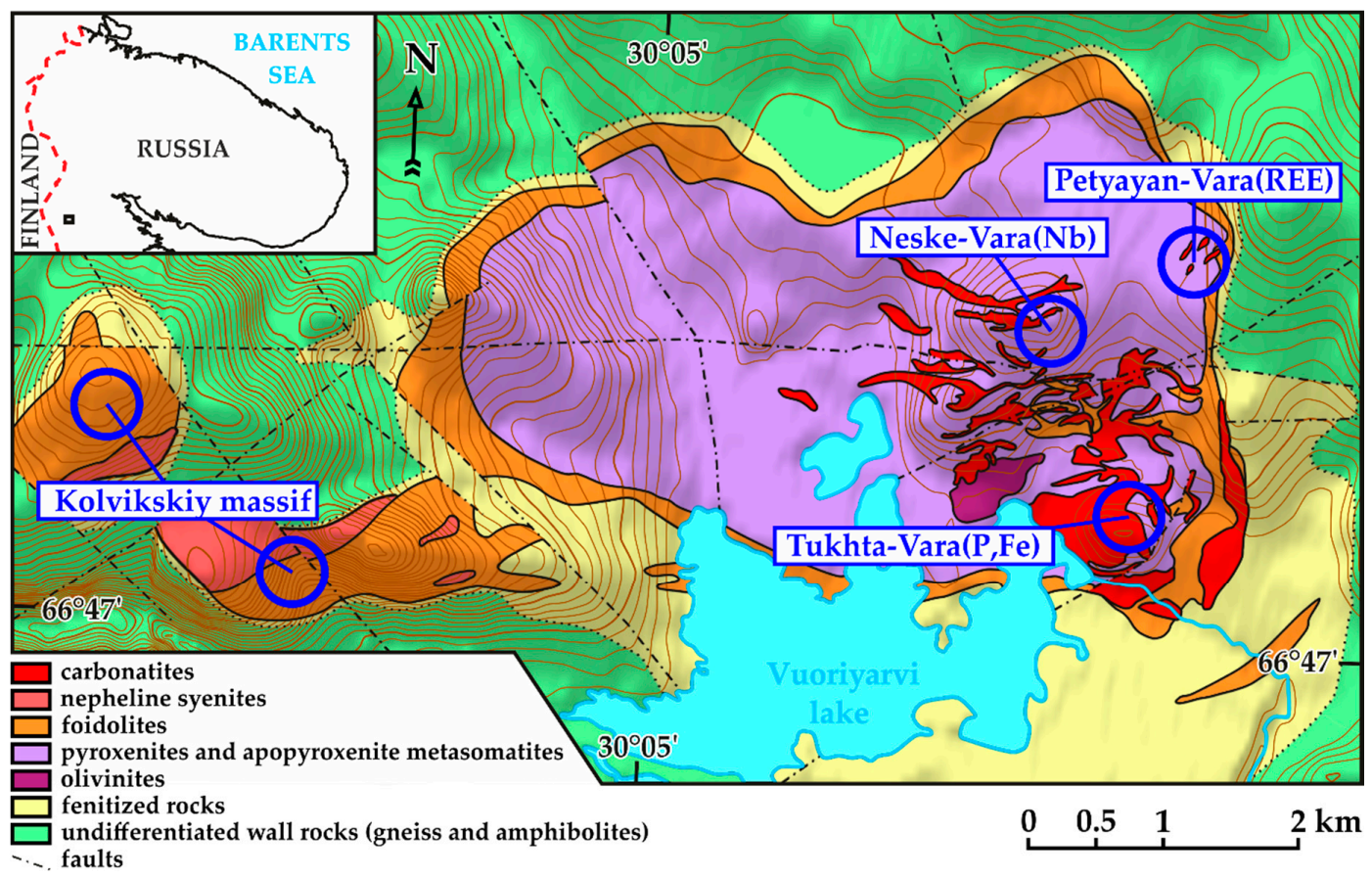

Figure 1. The geological setting and structure of the Vuoriyarvi alkaline-ultrabasic carbonatite complex simplified from [83]. Blue circles indicate the positions of the Tukhta-Vara, Neske-Vara, and Petyayan-Vara carbonatite fields and the Kolvikskiy agpaitic nepheline-syenite massif-satellite. 
This paper focuses on specific carbonatites from the eastern flank of the massif, which outcrops on the slope of the Petyayan-Vara hill. In this area, the country rocks are melteigites, ijolites, and pyroxenites. A considerable amount of pyroxenites was metasomatically altered, forming coarseand gigantic-grained phlogopite glimmerites, particularly in areas adjacent to carbonatite veins. Carbonatites occur as veins and lenses several hundred meters in length and up to tens of meters in width. In terms of chemical and mineral characteristics, carbonatites of Petyayan-Vara are extraordinary for the Vuoriyarvi massif. Most are magnesiocarbonatites (Figure 2), which we divided into five groups differing in mineral composition (Table 1):

1. Least altered magnesiocarbonatites;

2. High-Ti magnesiocarbonatites and silicocarbonatites with microcline and areas of apatite mineralization;

3. Magnesiocarbonatites with barium-strontium-rare earth mineralization;

4. Late calciocarbonatites;

5. Breccias of magnesiocarbonatites with rare-earth-silicate groundmass.

The listed rock varieties and their hybrids are the subjects of our study.

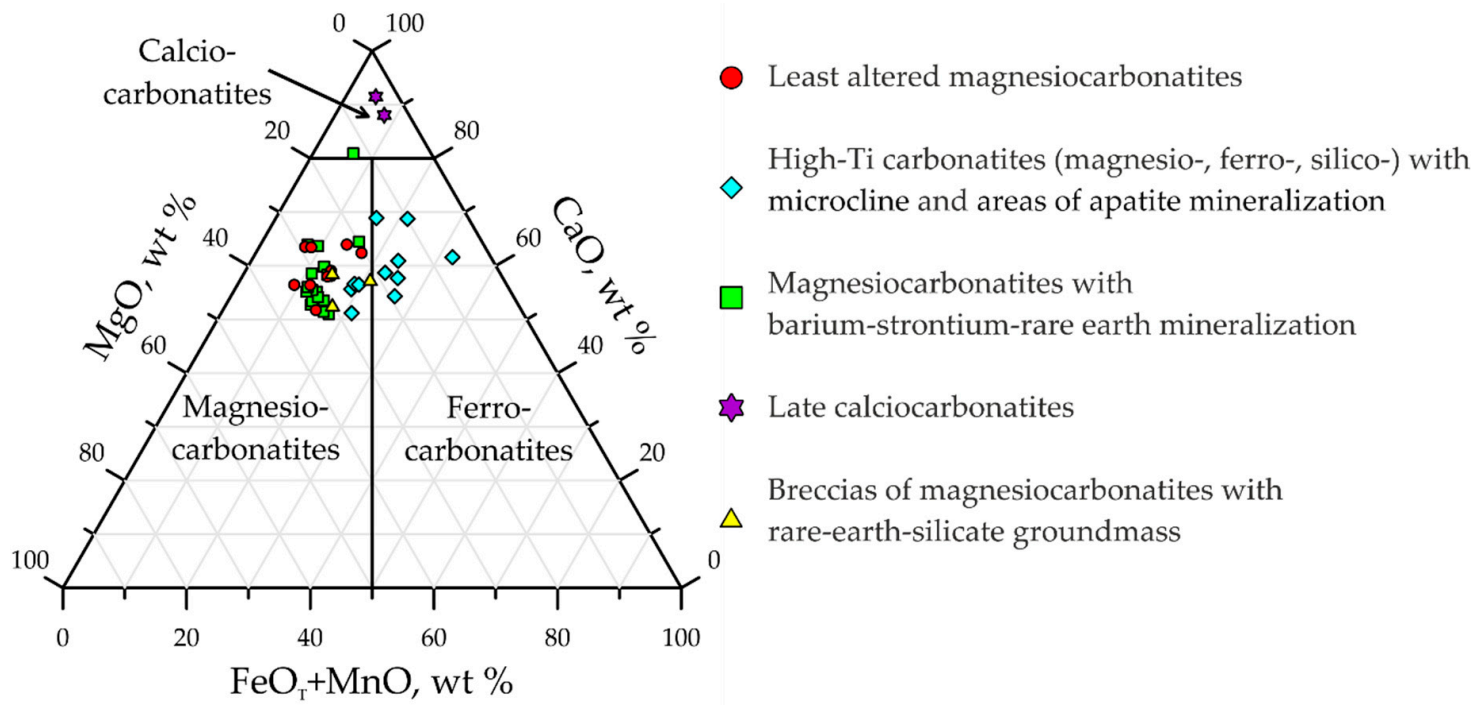

Figure 2. Composition points of the Petyayan-Vara carbonatites on the $\mathrm{CaO}-\mathrm{MgO}-(\mathrm{FeO}+\mathrm{MnO})$ (wt. \%) classification diagrams from $[3,86]$.

\section{Sampling Procedure and Analytical Methods}

For this study, 43 samples were collected from three geological cross-sections in different areas of the Petyayan-Vara field perpendicular to the strikes of late rare earth magnesiocarbonatite bodies. Five large veins and lenses, whose thicknesses range from 4 to $13 \mathrm{~m}$, were discovered during fieldwork.

\subsection{Petrographic Studies}

Microscopic observations were made on regular and polished thin sections. For the petrographic study, an Axioplan 2 Imaging (Carl Zeiss) microscope (Carl Zeiss, Oberkochen, Germany) was used. Mineral identification was aided by Raman spectroscopy performed using a HORIBA LabRAM HR 800 spectrometer (Horiba Ltd., Kyoto, Japan) with a $514.5 \mathrm{~nm}$ (green) exciting laser and a nominal output power of $50 \mathrm{~mW}$. 
Table 1. Mineral composition of the Petyayan-Vara carbonatites.

\begin{tabular}{|c|c|c|c|c|c|c|}
\hline Mineral, Mineral Formula & Abbr. & $(1) *$ & (2) & (3) & (4) & (5) \\
\hline Calcite, $\mathrm{CaCO}_{3}$ & Cal & + & ++ & +++ & +++ & + \\
\hline Dolomite, $\mathrm{CaMg}\left(\mathrm{CO}_{3}\right)_{2}$ & Dol & +++ & +++ & +++ & + & +++ \\
\hline Ankerite, $\mathrm{Fe}^{2+} \mathrm{Mg}\left(\mathrm{CO}_{3}\right)_{2}$ & Ank & & & + & & \\
\hline Kutnohorite, $\mathrm{Mn}^{2+} \mathrm{Mg}\left(\mathrm{CO}_{3}\right)_{2}$ & Kut & & & + & & \\
\hline Norsethite, $\mathrm{BaMg}\left(\mathrm{CO}_{3}\right)_{2}$ & Nor & & & + & & \\
\hline Strontianite, $\operatorname{Sr}\left(\mathrm{CO}_{3}\right)$ & Str & & + & +++ & & + \\
\hline Ancylite-(Ce), $\mathrm{Sr}(\mathrm{Ce}, \mathrm{La})\left(\mathrm{CO}_{3}\right)_{2}(\mathrm{OH}) \cdot \mathrm{H}_{2} \mathrm{O}$ & Anc & + & + & +++ & & \\
\hline Burbankite $* *,(\mathrm{Na}, \mathrm{Ca})_{3}(\mathrm{Sr}, \mathrm{Ba}, \mathrm{Ce})_{3}\left(\mathrm{CO}_{3}\right)_{5}$ & $\mathrm{Brb}$ & $(++)$ & & & & \\
\hline Carbocernaite, $(\mathrm{Sr}, \mathrm{Ce}, \mathrm{La})(\mathrm{Ca}, \mathrm{Na})\left(\mathrm{CO}_{3}\right)_{2}$ & $\mathrm{Cbc}$ & + & & & & \\
\hline Bastnäsite-(Ce), $(\mathrm{Ce}, \mathrm{La}) \mathrm{CO}_{3} \mathrm{~F}$ & Bas & & + & + & & + \\
\hline Hydroxylbastnäsite- $(\mathrm{Ce}),(\mathrm{Ce}, \mathrm{La}) \mathrm{CO}_{3}(\mathrm{OH})$ & Bas & & + & + & & ++ \\
\hline Synchysite- $(\mathrm{Ce}), \mathrm{CaCe}\left(\mathrm{CO}_{3}\right)_{2} \mathrm{~F}$ & Syn & & & + & & \\
\hline Baryte, $\mathrm{BaSO}_{4}$ & Brt & ++ & + & +++ & & + \\
\hline Fluorapatite, $\mathrm{Ca}_{5}\left(\mathrm{PO}_{4}\right)_{3} \mathrm{~F}$ & Ap & + & ++ & & & \\
\hline Monazite, $\mathrm{CePO}_{4}$ & Mnz & & + & + & & + \\
\hline Microcline, $\mathrm{KAlSi}_{3} \mathrm{O}_{8}$ & Mc & & +++ & & & \\
\hline Phlogopite, $\mathrm{KMg}_{3}\left(\mathrm{AlSi}_{3} \mathrm{O}_{10}\right)(\mathrm{F}, \mathrm{OH})_{2}$ & Phl & + & ++ & & & \\
\hline Aegirine, $\mathrm{NaFe}^{3+} \mathrm{Si}_{2} \mathrm{O}_{6}$ & Aeg & & ++ & & & \\
\hline Albite, $\mathrm{NaAlSi}_{3} \mathrm{O}_{8}$ & $\mathrm{Ab}$ & & + & & & \\
\hline Zircon, $\mathrm{ZrSiO}_{4}$ & Zrn & & + & & & \\
\hline Thorite, $\mathrm{ThSiO}_{4}$ & Thr & & & + & & \\
\hline Quartz, $\mathrm{SiO}_{2}$ & Qz & & ++ & ++ & & +++ \\
\hline Fluorcalciopyrochlore, $(\mathrm{Ca}, \mathrm{Na}) \mathrm{Nb}_{2} \mathrm{O}_{6} \mathrm{~F}$ & $\mathrm{Pcl}$ & + & + & & & \\
\hline Hydroxycalciopyrochlore, $(\mathrm{Ca}, \mathrm{a})_{2} \mathrm{Nb}_{2}(\mathrm{O}, \mathrm{OH})_{6}(\mathrm{OH})$ & Pcl & + & + & & & \\
\hline Kenoplumbopyrochlore, $(\mathrm{Pb}, \mathrm{\square})_{2} \mathrm{Nb}_{2} \mathrm{O}_{6}(\square, \mathrm{OH})$ & Pcl & + & + & & & \\
\hline Anatase, brookite, rutile ${ }^{* * *}, \mathrm{TiO}_{2}$ & Ti ox. & + & ++ & + & & \\
\hline Hollandite, $\mathrm{Ba}\left(\mathrm{Mn}^{4+}{ }_{6} \mathrm{Mn}^{3+}{ }_{2}\right) \mathrm{O}_{16}$ & Hol & & + & + & & \\
\hline 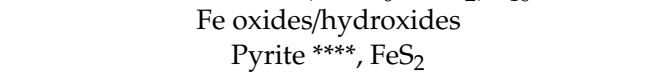 & $\begin{array}{l}\text { Fe ox. } \\
\text { Py }\end{array}$ & + & $\begin{array}{c}++ \\
+\end{array}$ & ++ & + & ++ \\
\hline
\end{tabular}

Abbr., mineral abbreviations used in the text, in Figures 3, 4, 6, 8, 10-16 and 18; ${ }^{*}$ The numbers correspond to the following carbonatite groups: (1) least altered magnesiocarbonatites; (2) high-Ti magnesiocarbonatites and silicocarbonatites; (3) magnesiocarbonatites with barium-strontium-rare earth mineralization; (4) late calciocarbonatites; and (5) breccias of magnesiocarbonatites with rare-earth-silicate groundmass. Maximum content of a mineral in a carbonatite group: " +++ "- more than $10 \mathrm{vol}$. \%, "++"-from 1 to $10 \mathrm{vol}$. \%, "+" - accessory phase $\left(<1\right.$ vol. \%); ${ }^{* *}$ Burbankite is pseudomorphically replaced, see Section 4.1.1; ${ }^{* * *}$ Mostly brookite; ${ }^{* * * *}$ Pyrite is the main sulfide mineral; $\square-$ vacancy.

\subsection{Scanning Electron Microscope (SEM)}

The chemical heterogeneity of the minerals was evaluated using backscattered electrons (BSE) images and maps of element distribution obtained via scanning electron microscopy (SEM). Mineral compositions were determined using a Hitachi S-3400N SEM (Hitachi Ltd., Tokio, Japan) coupled with an Oxford X-Max 20 energy dispersive X-ray spectrometer (EDS) $(20$ kV, $1 \mathrm{nA}, 30$ s exposure per spectra) (Oxford Instruments PLC, Reading, UK) and a Cameca MS-46 electron microprobe wavelength-dispersive spectrometer (WDS) $(22 \mathrm{kV}, 30 \mathrm{nA}, 50 \mathrm{~s}$ exposure per spectra) (Cameca, Paris, France). Both EDS and WDS spectrometers were calibrated using natural and synthetic compounds as standards. Most analyses were obtained by using an EDS. All spectra acquired by EDS were processed automatically using Oxford AzTec EDX software's True-Q procedure (AzTec 2.3, Oxford Instruments PLC, Reading, UK). Quartz ( $\mathrm{Si})$, corundum ( $\mathrm{Al})$, pyrite $(\mathrm{Fe}, \mathrm{S})$, apatite $(\mathrm{Ca}, \mathrm{P})$, periclase $(\mathrm{Mg})$, rhodochrosite $(\mathrm{Mn})$, albite $(\mathrm{Na})$, sylvite $(\mathrm{K}, \mathrm{Cl})$, barite $(\mathrm{Ba})$, monazite $(\mathrm{Ce})$, celestine $(\mathrm{Sr})$, and metallic $\mathrm{Ti}, \mathrm{Nb}, \mathrm{Ta}$, and $\mathrm{V}$ were used as standards. Mineral compositions were verified by individual WDS analyses. For WDS data calibration, the following phases and lines were chosen: wollastonite $(\mathrm{Si} K \alpha, \mathrm{CaK} \alpha)$, pyrope $(\mathrm{Al} K \alpha, \mathrm{MgK} \alpha)$, anatase $(\mathrm{Ti} K \alpha)$, hematite $(\mathrm{Fe} K \alpha), \mathrm{MnCO}_{3}(\mathrm{Mn} K \alpha)$, apatite $(\mathrm{P} K \alpha)$, lorenzenite $(\mathrm{NaK} \alpha)$, wadeite $(\mathrm{KK} \alpha)$, atacamite $(\mathrm{ClK} \alpha)$, zircon $(\mathrm{ZrL} \alpha)$, thorite $(\mathrm{ThM} \alpha)$, metallic $\mathrm{Nb}(\mathrm{Nb} L \alpha)$, metallic $\mathrm{Ta}(\mathrm{Ta} L \alpha)$, metallic $\mathrm{U}(\mathrm{UM} \alpha), \mathrm{SrSO}_{4}(\mathrm{SrL} \alpha), \mathrm{BaSO}_{4}(\mathrm{Ba} L \alpha, \mathrm{SK} \alpha), \mathrm{PbMoO}_{4}(\mathrm{~Pb} L \alpha), \mathrm{Y}_{3} \mathrm{Al}_{5} \mathrm{O}_{12}$ $(\mathrm{YL} \alpha),(\mathrm{La}, \mathrm{Ce}) \mathrm{S}(\mathrm{La} L \alpha), \mathrm{CeS}(\mathrm{Ce} L \alpha), \mathrm{LiNd}\left(\mathrm{MoO}_{4}\right)_{2}(\mathrm{Nd} L \alpha)$, and $\mathrm{SmFeO}_{3}(\mathrm{SmL} \alpha)$. The detection limit for $\mathrm{Si}, \mathrm{Ti}, \mathrm{Ca}, \mathrm{Fe}, \mathrm{K}$, and $\mathrm{Mn}$ was $0.02 \% ; 0.05 \%$ for $\mathrm{Al}, \mathrm{S}, \mathrm{P}, \mathrm{Cl}, \mathrm{Na}, \mathrm{Sr}, \mathrm{Ba}, \mathrm{Ta}, \mathrm{Y}, \mathrm{La}, \mathrm{Ce}, \mathrm{Nd}, \mathrm{Pr}$, and $\mathrm{Sm}$; and $0.1 \%$ for $\mathrm{Mg}, \mathrm{Zr}, \mathrm{Nb}, \mathrm{U}$, Th, and $\mathrm{Pb}$. The data were reduced using the original matrix 
correction technique [87]. At points investigated using WDS, the fluorine content was measured using an LEO-1450 SEM (Carl Zeiss AG, Oberkochen, Germany) equipped with an XFlash-5010 Bruker Nano GmbH EDS (20 kV, 0.5 nA, 200 s per exposure) (Bruker Nano GmbH, Berlin, Germany). Data reduction was performed using standard-free analysis based on the P/B-ZAF method of the QUANTAX system. Apatite was specifically analyzed with low amperage (0.5-1.0 nA) to avoid fluoride migration. Where possible, the spectra obtained in the spot mode were verified by areal analysis, in which the specific radiation dose per unit surface is much smaller. Changes in the quantities of substances, including fluorine, measured in point and area modes, were insignificant.

\subsection{Whole Rock Analysis}

\subsubsection{Major Elements}

The contents of major and volatile components were studied with the classical methods of "wet" chemistry. When analyzing the concentrations of $\mathrm{SiO}_{2}, \mathrm{Al}_{2} \mathrm{O}_{3}, \mathrm{Fe}_{2} \mathrm{O}_{3}, \mathrm{MgO}, \mathrm{TiO}_{2}$, and $\mathrm{SrO}$, average portions of the powered rock were decomposed by melting with borax and soda and were then transferred into the solution. A separate sample, also melted with borax and soda, was used to determine the $\mathrm{F}$ content, while $\mathrm{Cl}$ was analyzed after sintering with $\mathrm{KNaCO}_{3}$. Certain samples were decomposed by the acid in the mixture $\left(\mathrm{H}_{2} \mathrm{SO}_{4}+\mathrm{HNO}_{3}+\mathrm{HF}\right)$ to analyze the concentrations of $\mathrm{K}_{2} \mathrm{O}$, $\mathrm{Na}_{2} \mathrm{O}$, and $\mathrm{MnO}$; in mixture $\left(\mathrm{HNO}_{3}+\mathrm{HF}\right)$ to analyze $\mathrm{P}_{2} \mathrm{O}_{5}$; in mixture $\left(\mathrm{H}_{2} \mathrm{SO}_{4}+\mathrm{HF}\right)$ to analyze $\mathrm{FeO}$; and in nitric acid to calculate $\mathrm{S}$ content. To analyze $\mathrm{CO}_{2}$ content, the tested powder was previously exposed to $\mathrm{NaOH}$. Analyses of $\mathrm{SiO}_{2}, \mathrm{Al}_{2} \mathrm{O}_{3}, \mathrm{Fe}_{2} \mathrm{O}_{3}, \mathrm{MgO}, \mathrm{CaO}$, and $\mathrm{SrO}$ were carried out using the atomic absorption method; those of $\mathrm{K}_{2} \mathrm{O}, \mathrm{Na}_{2} \mathrm{O}$, and $\mathrm{MnO}$ with the emission method; $\mathrm{TiO}_{2}$ and $\mathrm{P}_{2} \mathrm{O}_{5}$ with the colourimetric method; $\mathrm{F}$ and $\mathrm{Cl}$ via direct potentiometric determination; $\mathrm{CO}_{2}$ and $\mathrm{FeO}$ with titration; and $\mathrm{S}_{\mathrm{T}}, \mathrm{H}_{2} \mathrm{O}^{+}$, and $\mathrm{H}_{2} \mathrm{O}^{-}$gravimetrically. The analytical errors were $1.5 \%$ for concentrations $>10 \mathrm{wt}$. $\%$ and $3.5 \%$ for concentrations between 1 and $10 \mathrm{wt}$. \%.

\subsubsection{Trace Elements}

The concentrations of trace elements were determined by inductively coupled plasma emission mass spectrometry (ICP-MS) on an ELAN 9000 DRC-e quadrupole mass spectrometer (PerkinElmer Inc., Shelton, CT, USA). For this procedure, each sample was completely transferred into the solution after acid decomposition in glassy carbon crucibles by gradually adding distilled HF (triple addition and evaporation to wet salts) and $\mathrm{HNO}_{3}$. The resulting sample solutions were diluted in such a way that the intensities of the analytical signals corresponded to the selected calibration ranges. The precision of the ICP-MS measurements was better than $\pm 5 \%$ for most elements.

\section{Results}

\subsection{Carbonatite Mineralogy and Mineral Chemistry}

\subsubsection{Least Altered Magnesiocarbonatites}

Magnesiocarbonatites are the protoliths for most other carbonatites of the Petyayan-Vara. They are characterized by a medium-grained texture and consist of hypidiomorphic dolomite crystals and large (up to few centimetres in diameter) red aggregates of calcite, strontianite, ancylite-(Ce) and baryte which likely pseudomorph another, unknown, mineral (Figure 3a-c). In accessory quantities, quartz and a mineral roughly consistent with the stoichiometry of carbocernaite were found. The primary matrix dolomite (Dol-0) of the magnesiocarbonatites hosts submicron isometric calcite, carbocernaite, and/or burbankite, as well as idiomorphic grains of magnetite (Figure 3d). This dolomite has low contents of the ankerite (Ank; $6 \pm 2$ mol. \%) and kutnohorite (Kut; $3 \pm 1 \mathrm{~mol} . \%)$ components and contains up to $1.0 \mathrm{wt}$. \% SrO. Around the cracks with late secondary mineralization, the dolomite (Dol-1) composition is different (17 \pm 6 mol. \% Ank, $7 \pm 4$ mol. \% Kut, without Sr). 

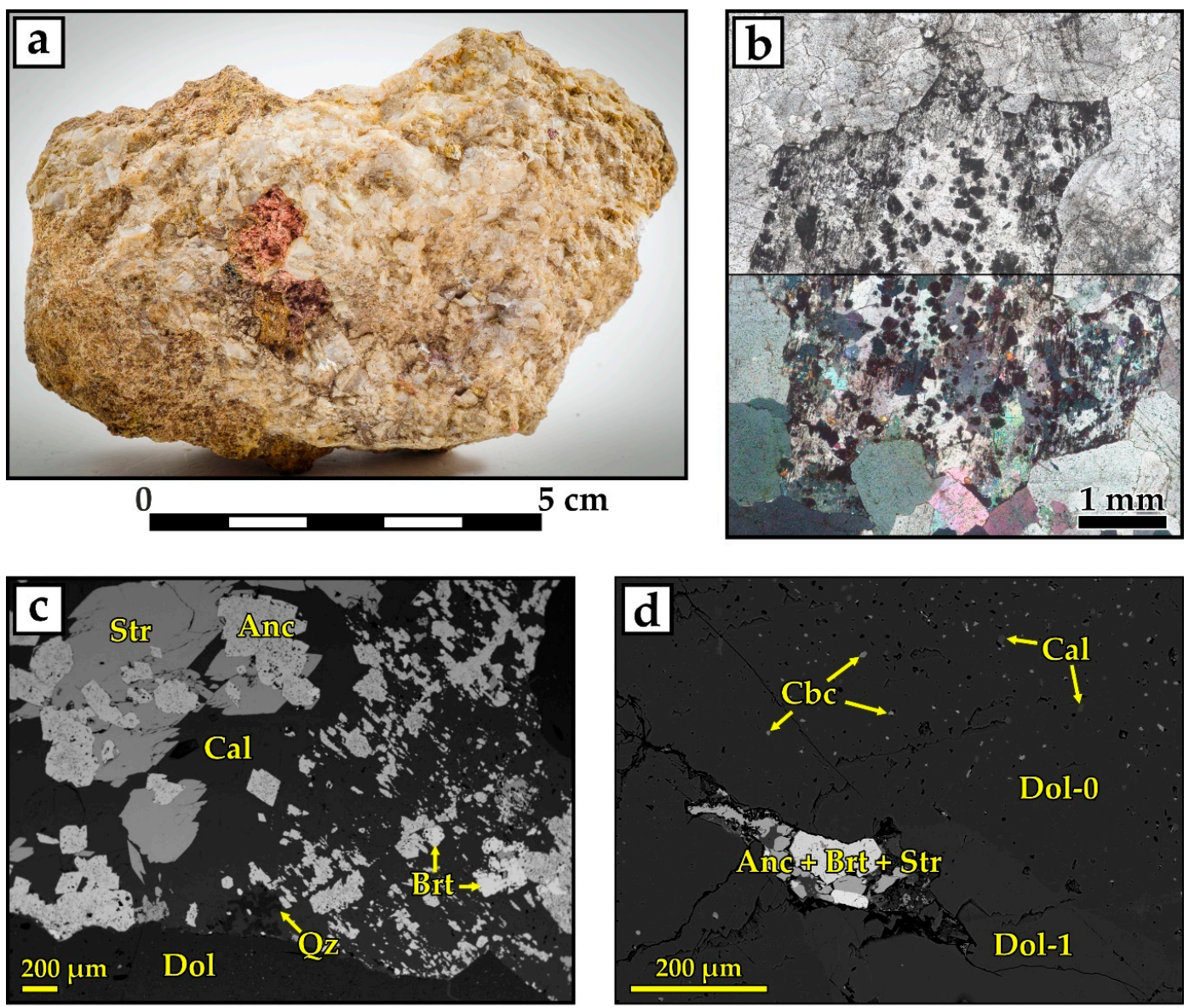

Figure 3. Least altered magnesiocarbonatite. (a) Whole-rock sample with red colored polymineral pseudomorphs in the dolomite matrix. (b) General view and (c) a fragment of the polymineral pseudomorph; (d) Fe-Mn-poor dolomite (Dol-0) with a variety of inclusions (the dark grey inclusions are calcite; the light ones are carbocernaite and burbankite). Near the cracks, Dol-0 is replaced by Fe-Mn-rich inclusion-free Dol-1. Photomicrograph (b) in transmitted light [top-in plane-polarized light, bottom-in cross-polarized light], (c,d) in backscattered electrons (BSE).

\subsubsection{High-Ti Carbonatites with Areas of Apatite Mineralization}

High-Ti carbonatite (with over $1 \mathrm{wt}$. \% of $\mathrm{TiO}_{2}$ ) is dense red and brown rock with a fine crystalline carbonate matrix. Macroscopically, this rock resembles the classical rødbergite of the Fen massif (Norway) $[58,88]$. The high-Ti carbonatites of the Petyayan-Vara are localized within selvages of carbonatite bodies and constitute veins several meters in thickness. The morphology of the contacts between these veins and magnesiocarbonatites is irregular but sharp (Figure 4a). Several thin (of about $1 \mathrm{~cm}$ and less in thickness) veinlets of high-Ti carbonatite cut least altered magnesiocarbonatites.

In all high-Ti carbonatites of the Petyayan-Vara, the principal minerals are dolomite, sodiumand barium-free microcline, and and Fe-Ti oxides. The mineral abundance of these carbonatites is variable, and quartz, calcite, Ti-rich phlogopite, apatite, Ti-rich aegirine, and albite are present in lesser amounts, or absent. Sulfides, magnetite, zircon, pyrochlore, strontianite, baryte, ancylite-(Ce), and monazite were found as accessory phases. Feldspars and sulfides (mainly pyrite) are widespread only in high-Ti carbonatites (in later metasomatic rocks, sulfur is accommodated almost exclusively in baryte). Phlogopite, apatite, zircon, and pyrochlore also occur within mineralized veinlets in the magnesiocarbonatites surrounding high-Ti carbonatites. 

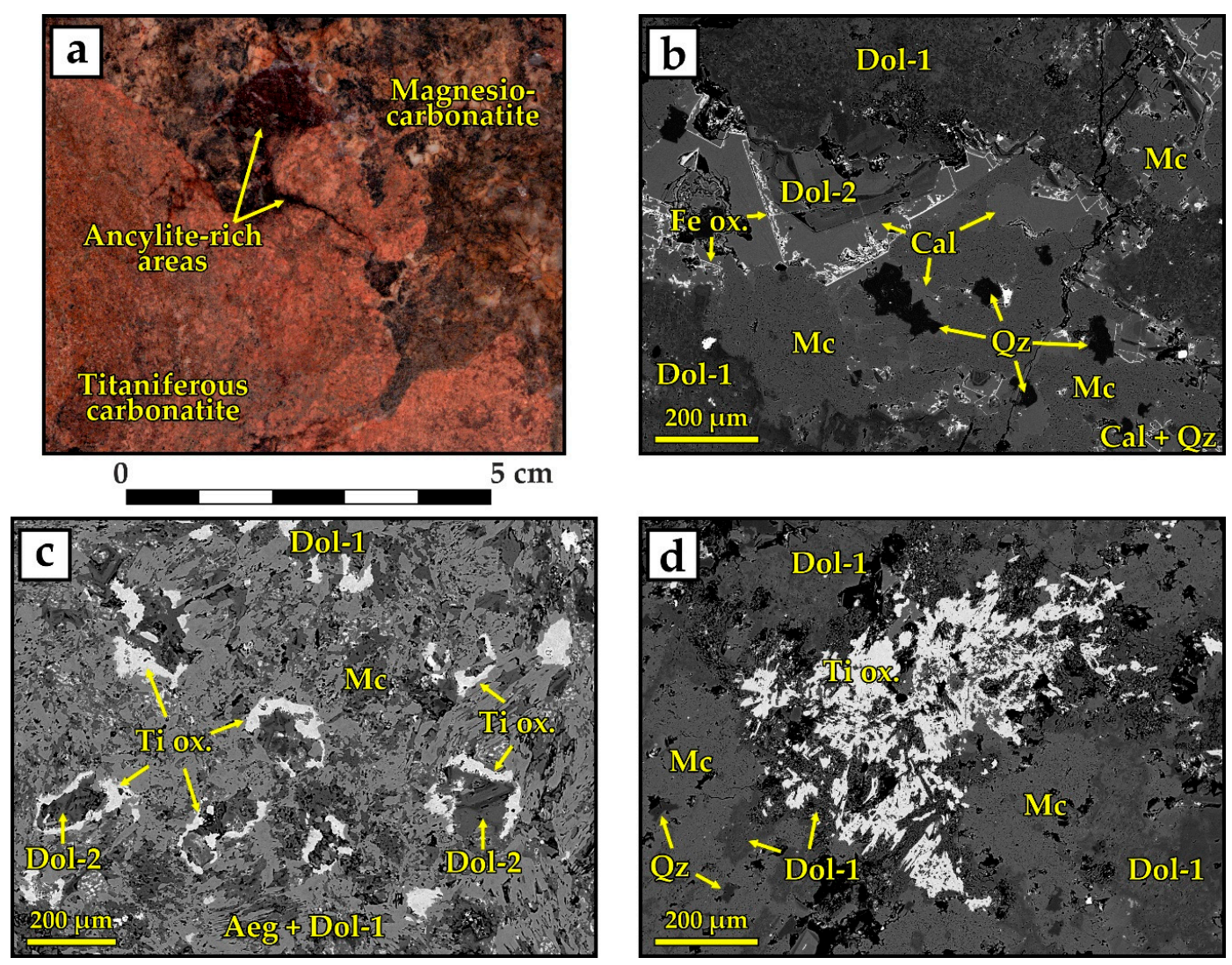

Figure 4. High-Ti carbonatite. (a) Polished sample from the contact of high-Ti carbonatite and least altered magnesiocarbonatite. The dark red area contains abundant ancylite. (b) A mineralized crack filled with late calcite, quartz, and zoned Dol-2 in the groundmass of the microcline and spongy dolomite Dol-1. (c) Fragment of zoned Dol-2, isolated from spongy Dol-1, aegirine, and the microcline by the rims of titanium oxides. (d) Titanium oxides, intergrown with dolomite and microcline. Photomicrographs (b-d) were imaged in backscattered electron (BSE) mode.

Dolomite in these rocks is represented by two generations. The earliest generation (Dol-1), comprising the bulk of high-Ti carbonatites, is turbid, spongy, and xenomorphic (Figure $4 \mathrm{~b}$ ). This generation is chemically heterogeneous due to variability in its $\mathrm{Mg} / \mathrm{Fe}$ ratio $(19 \pm 8 \mathrm{~mol}$. \% Ank). Its manganese content is low $(3 \pm 4 \mathrm{~mol} . \% \mathrm{Kut})$. The spongy dolomite is chemically similar to dolomite Dol-1 from the unaltered magnesiocarbonatites (Fe-rich, without Sr). Dol-1 from high-Ti carbonatites hosts abundant inclusions of Fe oxides and hydroxides (mostly goethite and hematite). The late generation dolomite Dol-2 is adjacent to the selvages of mineralized fractures. Dol-2 differs from Dol-1 in its compact morphology, optical clarity, idiomorphic appearance, and fine oscillatory zoning (Figure $4 \mathrm{~b}$ ). Compared with Dol-1, Dol-2 contains significantly less $\mathrm{Mg}$ and $\mathrm{Mn}$, and its content is much less variable ( $4 \pm 3 \mathrm{~mol} . \% A n k, 3 \pm 2 \mathrm{~mol} . \% \mathrm{Kut}$, without $\mathrm{Sr}$ ). Dol-2 occurs sporadically in the groundmass composed of Dol-1. There, Dol-2 occurs as grains isolated from spongy Dol-1 by rims of titanium oxides (Figure 4c).

Potassium feldspar is predominantly a microcline of an unusual goldish-yellow color with no visible twinning in the thin section. Microcline occurs as xenomorphic spongy grains like those of Dol-1 (see Figure 4b). Chemically, this phase is pure $(\mathrm{Na}, \mathrm{Ba}$, and $\mathrm{Sr}$ are below detection limit of WDS). However, this phase contains abundant fluid and solid-phase microinclusions, giving it a turbid appearance. The microcline penetrates both the groundmass and late mineralized fractures. Where coexistent with phlogopite, microcline typically replaces the mica pseudomorphically. In high-Ti carbonatites, the bulk of the silica is concentrated in microcline. Moreover, in many high-Ti carbonatites samples, the $\mathrm{SiO}_{2}$ content exceeds $20 \mathrm{wt}$. \% and are therefore, nominally classified as silicocarbonatites. 
High-Ti carbonatites host 5 vol. \% and greater titanium oxides (Ti-oxides hereafter), which are intergrown with dolomite (mainly Dol-1), microcline, and phlogopite (Figure 4d). Ti-oxides occur as three polymorphic varieties: anatase, rutile, and brookite. In high-Ti carbonatites, their total abundance is high (from 0.9 to $4.4 \mathrm{wt}$. \% $\mathrm{TiO}_{2}$ in the rock, with a median of $2.3 \mathrm{wt}$. \% for 11 samples). The most common polymorph is brookite, while anatase is less abundant. Sparse rutile occurs paramorphically on both minerals. In association with the late generations of $\mathrm{Nb}$-rich Ti-oxides and late dolomite, well-preserved idiomorphic grains of pyrochlore were detected. Typically, these grains' compositions are $\mathrm{Ca}_{1.1} \mathrm{Na}_{0.9} \mathrm{Fe}_{0.1} \mathrm{Nb}_{1.8} \mathrm{Ti}_{0.2} \mathrm{O}_{6} \mathrm{~F}$, which corresponds to fluorcalciopyrochlore [89]. Hydroxycalciopyrochlore and kenoplumbopyrochlore are less abundant [90]. Magnesiocarbonatites were overprinted by Ti-rich carbonatitic fluids as evidenced by fine veinlets. Only increased $\mathrm{TiO}_{2}$ content (up to $1.1 \mathrm{wt}$. \%) differentiates magnesiocarbonatites with veinlets from the other primary dolomite carbonatites, as described in Section 4.1.1. Occasionally, pyrochlore clusters (+ magnetite and Ti-depleted phlogopite) occur without Ti-oxides in magnesiocarbonatites, bordering the high-Ti rocks. In these rocks, the concentration of $\mathrm{Nb}$ reaches $1500 \mathrm{ppm}$, with an average $\mathrm{Nb}$ concentration of 400-800 ppm in high-Ti varieties and 10-100 ppm in other carbonatites of the Petyayan-Vara. Niobium deportment in these rocks is shown in the $\mathrm{Nb}-\mathrm{Nb} / \mathrm{Ti}$ diagram (Figure 5).

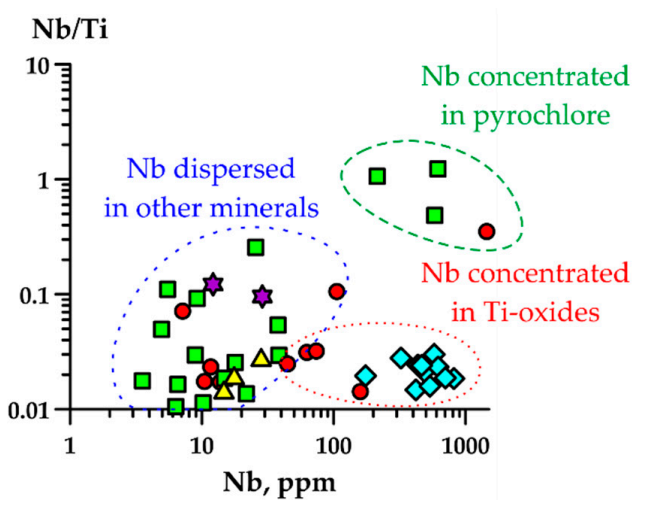

Least altered magnesiocarbonatites

High-Ti carbonatites (magnesio-, ferro-, silico-) with

$\diamond$ microcline and areas of apatite mineralization

Magnesiocarbonatites with

barium-strontium-rare earth mineralization

Late calciocarbonatites

Breccias of magnesiocarbonatites with

$\triangle$ rare-earth-silicate groundmass

Figure 5. Composition points of carbonatites of the Petyayan-Vara on the $\mathrm{Nb}-\mathrm{Nb} / \mathrm{Ti}$ diagram.

Samples in Figure 5 are grouped as follows: (1) rocks that contain pyrochlore mineralization and are free of Ti-oxides (with high $\mathrm{Nb}$ content and $\mathrm{Nb} / \mathrm{Ti}$ ratio of $0.4-1.2$ ); (2) high-Ti carbonatites and least altered magnesiocarbonatites hosting $\mathrm{TiO}_{2}$-carbonate veinlets (with high $\mathrm{Nb}$ content and a $\mathrm{Nb} / \mathrm{Ti}$ ratio of 0.01-0.03); and (3) rocks free of both pyrochlore and Ti-oxides (with low $\mathrm{Nb}$ content and a variable $\mathrm{Nb} / \mathrm{Ti}$ ratio). The high $\mathrm{Nb}$ contents in combination with the low $\mathrm{Nb} / \mathrm{Ti}$ ratios suggest that Ti-oxides are the principal niobium concentrators in high-Ti carbonatites (as well as the Petyayan-Vara carbonatites in general), which is typical of the late-stage carbonatites of many other complexes worldwide (e.g., [91-93]).

In most high-Ti rocks, fluorapatite is scarce and $\mathrm{P}_{2} \mathrm{O}_{5}$ content is about $0.2-0.5 \mathrm{wt}$. \%, which is similar to the $\mathrm{P}_{2} \mathrm{O}_{5}$ content in other varieties of the Petyayan-Vara carbonatites. In contrast, some areas of high-Ti rocks contain up to $7.5 \mathrm{wt}$. $\% \mathrm{P}_{2} \mathrm{O}_{5}$. In these rocks composed of apatite + calcite \pm Ti-rich aegirine assemblages, apatite occurs as a vein network intersecting the groundmass. Like the veinlets with Ti-oxides, those with apatite were found in several samples of the least altered magnesiocarbonatites surrounding the high-Ti carbonatites. Apatite forms clusters of anhedral grains (Figure 6a), rims on various minerals (e.g., sulfides, see Figure 6b), and radial aggregates of small euhedral crystals (Figure 6c). Anhedral grains represent the earliest apatite generation (Ap-1) and mainly occur in the carbonate groundmass as apatite-rich spots, while the rims and idiomorphic crystals of apatite (Ap-2) are distributed along the fractures. Anhedral grains of Ap-1 are almost free of impurities (up to a maximum of 0.5 wt. $\% \mathrm{Na}_{2} \mathrm{O}, 0.8 \mathrm{wt}$. $\% \mathrm{SiO}_{2}$, and $0.9 \mathrm{wt}$. \% SrO; the content of other impurities is below the detection limit). 

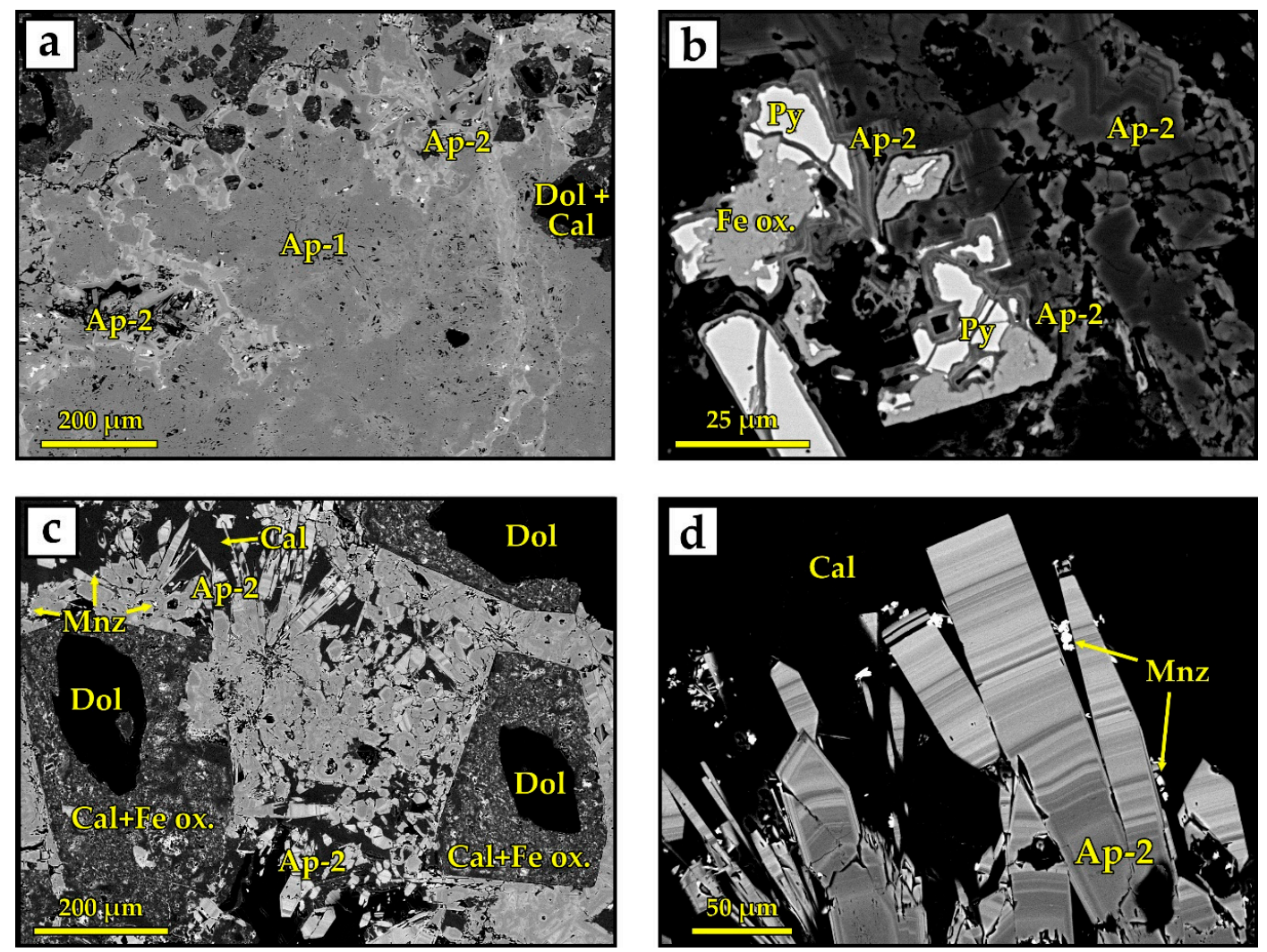

Figure 6. Apatite in high-Ti carbonatite. (a) Clusters of porous anhedral grains of the early apatite (Ap-1) and late zoned apatite (Ap-2), bordering Ap-1, as veinlets and cavity-fillings. (b) Concentrically banded Ap-2 rims around pyrite grains. (c) Radial aggregates of small euhedral Ap- 2 crystals. Dolomite in contact with Ap-2 is replaced by calcite and included with Fe-hydroxides. (d) Ap-2 with a horizontal fine oscillatory zoning pattern (light gray bands-with $\mathrm{Na}+\mathrm{REEs}$; dark gray-with $\mathrm{Sr}+\mathrm{S}$ ) and monazite (small white crystals). All photomicrographs are BSE images.

In contrast, the composition of both the rims and idiomorphic crystals of late apatite Ap-2 is highly variable, even within a single grain. On the BSE images, this compositional variability is expressed as fine oscillatory zoning (Figure $6 \mathrm{~d}$ ). In Ap-2, $\mathrm{SO}_{3}$ content varies in the range of $0.4-1.3 \mathrm{wt}$. \%, SrO concentration reaches 3.0 wt. $\%, \mathrm{Na}_{2} \mathrm{O}$ reaches $3.0 \mathrm{wt}$. \%, and ThO reaches 0.9 wt. \%. Total $\mathrm{REE}_{2} \mathrm{O}_{3}$ content is $8.8 \mathrm{wt}$. \%, with increased content of heavy REE (up to $0.6 \mathrm{wt} . \% \mathrm{Gd}_{2} \mathrm{O}_{3}$ and $1.9 \mathrm{wt}$. \% $\mathrm{Y}_{2} \mathrm{O}_{3}$ ). A positive correlation between $\mathrm{Sr}$ and $\mathrm{S}$ indicates the joint occurrence of these elements in the structure of Ap-2 (Figure 7a). A similar positive correlation is observed between Na and REE (Figure $7 \mathrm{~b})$. However, the correlation between the contents of $(\mathrm{Sr}+\mathrm{S})$ and $(\mathrm{Na}+\mathrm{REE})$ is inverse (Figure 7c). The zoning in Ap-2 can thus be explained by the successive alternation of apatite sites enriched with either $\mathrm{Sr}$ and $\mathrm{S}$ or Na and REE (the dark and light apatite zones in Figure 6d, respectively). Nevertheless, Sr and S mainly accumulated during the initial stage of Ap-2 growth, and Na and REE mostly accumulated during the later stage (see Figure $6 \mathrm{~d}$ ). 

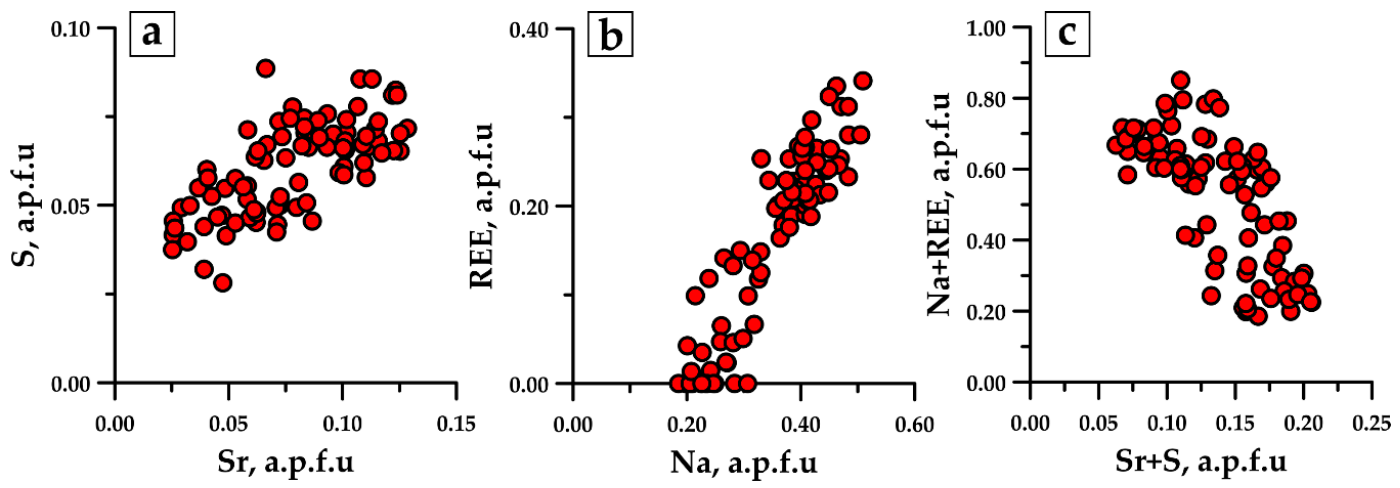

Figure 7. (a-c) Relationship between the contents of $\mathrm{Sr}, \mathrm{S}$, Na, and $\mathrm{REE}(\mathrm{REE}=\mathrm{Y}+\mathrm{La}+\mathrm{Ce}+\mathrm{Nd})$ in late apatite Ap-2, in atoms per formula unit (a.p.f.u.).

Calcite is associated with apatite in veins and pseudomorphically replaces dolomite near the late idiomorphic apatite crystals (see Figure 4c). In pseudomorphs, calcite commonly hosts inclusions of Fe-hydroxides.

Zircon occurs as microinclusions, anhedral segregations in apatite, and overgrowths on apatite edges. Similar relationships between zircon and sulfate-rich fluorapatite were discovered in other complexes-for example, in the Khaluta carbonatite massif, Russia [79].

As noted above, strontianite, baryte, and ancylite-(Ce) are accessory phases in high-Ti carbonatites. The individual grains and small clusters of these minerals were detected in cavities and fractures of high-Ti carbonatite (Figure 8a), often in combination with late HREE-rich apatite.

Monazite-(Ce) and bastnäsite-(Ce) crystallized later than the Ba-Sr-REE assemblages. In the intersections between the monazite veinlets and cavity-filling Ba-Sr-REE assemblage, ancylite is pseudomorphically replaced by monazite (Figure $8 b$ ). In most cases, monazite is spatially associated with apatite (Figure 8c). In some samples, both Dol-1 and Dol-2 are partially replaced by monazite (Figure 8d). Monazite is enriched in $\mathrm{CaO}, \mathrm{SrO}$, and $\mathrm{BaO}$ (by several percent) and contains up to $5.4 \mathrm{wt} . \% \mathrm{SO}_{3}$. This, however, is typical for carbonatites of the Vuoriyarvi massif [94]. Th-bearing monazite (up to $2.3 \mathrm{wt}$. \% ThO) often accompanies Th-bearing apatite. Most analyses of monazite showed a mass deficit. In addition to monazite, rhabdophane is also common in carbonatites $\left[\mathrm{Ce}\left(\mathrm{PO}_{4}\right) \cdot \mathrm{H}_{2} \mathrm{O}\right]$ (e.g., [71,80,95-97]). The proportions of REE:P in this mineral are the same as those in monazite, but rhabdophane analyses show a mass deficit due to the presence of water in its structure. These minerals also differ in structure: Monazite crystallizes in a monoclinic system, space group $P 2_{1} / n, Z=4$; and rhabdophane crystallizes in a hexagonal system, space group $P 6_{2} 22, Z=2$. To verify the diagnosis of monazite, we examined its structure by Raman spectroscopy. The Raman spectra of rhabdophane and monazite in the region of $400-1200 \mathrm{~cm}^{-1}$ show the same set of bands with similar positions (Table 2). Because of the water in the structure of rhabdophane, its spectrum contains additional bands near $3500 \mathrm{~cm}^{-1}$ [98-101]. The monazite spectra from the Petyayan-Vara carbonatites show no bands in this region (Figure 3a); therefore, these monazite grains are anhydrous. Spectra of monazite show all bands characteristic of this mineral and most show an additional band of variable intensity at $1088 \mathrm{~cm}^{-1}$, the main band of calcite [102,103]. Thus, an excess of Ca is most likely a consequence of the monazite-calcite intergrowth, and the mass deficit is caused by the presence of $\mathrm{CO}_{3}$ bound in calcite, which was not considered in the analyses. 

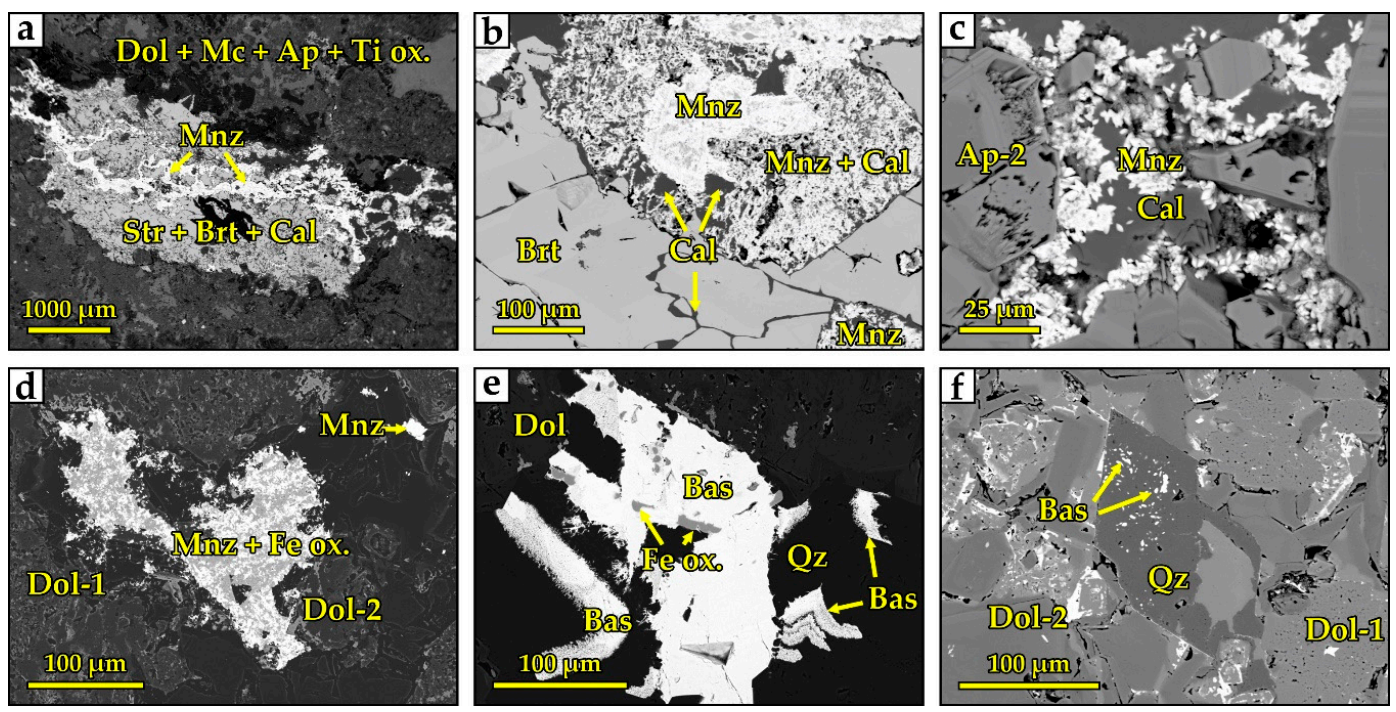

Figure 8. Secondary mineral assemblages of high-Ti carbonatites. (a) Baryte, ancylite, strontianite, calcite, quartz, and brookite surrounded by resorbed dolomite in a cavity. (b) Monazite formed near the late apatite. (c) A monazite vein that intersects a cavity with baryte-strontianite mineralization. (d) Partial replacement of dolomite with clusters of monazite and iron oxides. (e) Porous bastnäsite in association with collomorphic quartz cementing the latest cracks. (f) bastnäsite microinclusions in idiomorphic quartz crystal. All photomicrographs are BSE images.

Table 2. Assignment of the vibrations of the main bands and their Raman frequencies $\left(\mathrm{cm}^{-1}\right)$ for monazite, rhabdophane, calcite, bastnäsite, and hydroxylbastnäsite.

\begin{tabular}{cccccc}
\hline Band Assignment & Monazite & Rhabdo-Phane & Calcite & Bastnäsite & Hydroxyl-Bastnäsite \\
\hline Lattice modes & up to 430 & up to 300 & up to 320 & up to 300 & up to 500 \\
$v_{2}\left(\mathrm{PO}_{4}\right)$ out-of-plane bending & $465-478$ & $468-474$ & - & - & - \\
$v_{4}\left(\mathrm{PO}_{4}\right)$ in-plane bending & $618-634$ & $613-622$ & - & - & - \\
$v_{4}\left(\mathrm{CO}_{3}\right)$ in-plane bending & - & - & $711-716$ & $720-740$ & $570-740$ \\
$v_{2}\left(\mathrm{CO}_{3}\right)$ out-of-plane bending & - & - & - & $840-870$ & $780-930$ \\
$v_{1}\left(\mathrm{PO}_{4}\right)$ symmetric stretching & $965-990$ & $963-985$ & - & - & - \\
$v_{3}\left(\mathrm{PO}_{4}\right)$ asymmetric stretching & $1054-1075$ & $1020-1056$ & - & - & - \\
$v_{1}\left(\mathrm{CO}_{3}\right)$ symmetric stretching & - & - & $1084-1092$ & $1085-1098$ & $1080-1098$ \\
$v_{3}\left(\mathrm{CO}_{3}\right)$ asymmetric stretching & - & - & $1432-1437$ & $1432-1538$ & $\sim 1400$ \\
$v\left(\mathrm{H}_{2} \mathrm{O}\right)$ stretching & - & $\sim 3500$ & - & - & $\sim 3500$ \\
\hline References: & {$[98-100]$} & {$[99,101]$} & {$[102,103]$} & {$[104,105]$} & {$[104,105]$} \\
\hline
\end{tabular}

* In the $\mathrm{CO}_{3}$ symmetrical stretching region, calcite and bastnäsite have one band each, and hydroxylbastnäsite has three bands at 1080, 1087, and $1098 \mathrm{~cm}^{-1}$ [104].

Bastnäsite occurs as dense, cavity-filling, xenomorphic masses. Sporadically, porous bastnäsite (Figure 8e) was observed in association with collomorphic quartz filling the latest cracks. Rarely, quartz crystals host bastnäsite microinclusions (Figure 8f). The F content in bastnäsite varies from 0 to $5 \mathrm{wt}$. \%. Although hydroxylbastnäsite-(Ce) is a rare mineral, the Petyayan-Vara field is its type locality [106]. Raman spectroscopy was used to check whether variations in the F content in bastnäsite are related to its substitution with $(\mathrm{OH})$. The spectra of bastnäsite and hydroxylbastnäsite are fairly similar (see Table 2). However, bastnäsite shows one peak in the $1080-1090 \mathrm{~cm}^{-1}$ region and no peaks in the $3500-3600 \mathrm{~cm}^{-1}$ region, while hydroxylbastnäsite shows three peaks in the $1080-1090 \mathrm{~cm}^{-1}$ region and several peaks in the region of $3500-3600 \mathrm{~cm}^{-1}$ due to the presence of an $(\mathrm{OH})$-group in the latter [104]. Raman spectra of both bastnäsite sensu stricto (with F) and hydroxylbastnäsite (with $\mathrm{OH}$ ) were observed in high-Ti carbonatites (Figures $9 b$ and $9 c$, respectively). Further research showed that these two phases coexist in all other bastnäsite-containing varieties of the Petyayan-Vara carbonatites (see Sections 4.1.3 and 4.1.5). For simplicity, both minerals are hereafter referred to as "bastnäsite". 
Both monazite and bastnäsite are often surrounded by or intergrown with oxides and hydroxides of Fe (hereafter, Fe-oxides).
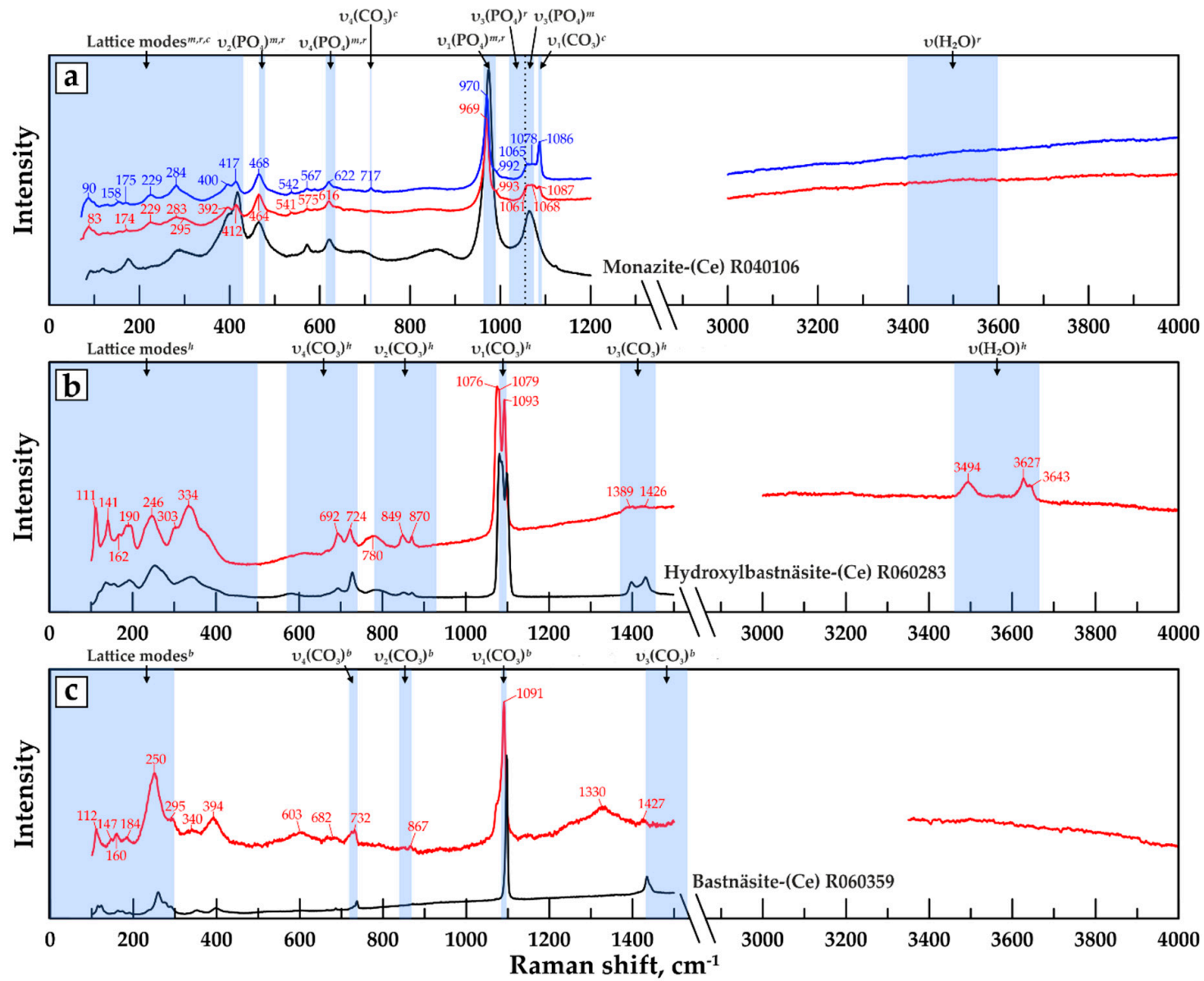

Figure 9. Raman spectra of (a) monazite-(Ce), (b) hydroxylbästnasite-(Ce), and (c) bästnasite-(Ce) from high-Ti carbonatites of the Petyayan-Vara (red and blue lines). Spectra (black lines) and ID references of minerals are from the RRUFF database [107]. The positions of the main bands (see Table 2) of monazite $(m)$, rhabdophane $(r)$, calcite $(c)$, hydroxylbästnasite $(h)$, and bästnasite $(b)$ are plotted.

\subsubsection{Barium-Strontium-Rare Earth Carbonatites}

Barium-strontium-rare earth carbonatites are the most abundant rocks among carbonatite veins. Several variations were observed petrographically. Their common feature is the abundance of baryte, ancylite, and/or strontianite. The observed mineral assemblages are named according to the dominant mineral (in the sequence of formation): (1) Baryte, (2) ancylite, and (3) strontianite. The first and second assemblages are the most abundant, and the third was detected at only a few sites.

Minerals of the baryte assemblage reside in fine-grained, brown colored mineralized dissolution cavities (Figure 6a) of the magnesiocarbonatites. There, baryte and late-stage dolomite constitute collomorphic clusters (Figure 6b). Compositionally, late-stage dolomite is similar to the Dol-2 from high-Ti carbonatites (Fe-poor and Sr-free, see Section 4.1.2). A significant part of this assemblage is composed of oxides and hydroxides of Fe and Mn, which commonly occur as zoned spherical aggregates with a collomorphic appearance (Figure 6c). The accessory mineral phases of the baryte assemblage are represented by sulfur-bearing monazite, which is often overgrown by bastnäsite (Figure 6d), as well as hollandite and norsethite. Most bastnäsite is hydrated (hydroxylbastnäsite is prevalent). Calcite and ancylite occur locally. In samples composed predominantly of this assemblage, the $\mathrm{BaO}$ content can reach 17 wt. \%. 
The ancylite assemblage consists primarily of ancylite (main phase), baryte, strontianite, calcite, and, occasionally, quartz. Rocks with this assemblage have a reddish color due to the abundance of Fe oxides and hydroxides inside the ancylite grains and interstices. Commonly, this mineralization fills either submillimeter veinlets or small cavities. Such cavities were observed in magnesiocarbonatite, baryte-rich carbonatite, and rarely in high-Ti carbonatite. This suggests a stage during which dissolution occurred between the formation of baryte and ancylite assemblages (see inset on Figure 10a). Magnesiocarbonatite samples with filled cavities and veinlets have a total REE oxide content of 1-3 wt. \%. In many Petyayan-Vara carbonatite veins, the total REE oxide contents are much higher ( $\geq 10$ wt. \% total $\mathrm{REE}_{2} \mathrm{O}_{3}$ ). This enrichment is explained by the presence of (Figure 11a-c): (1) large areas of corrosion, in which the primary dolomite was dissolved and replaced by minerals of the ancylite assemblage; (2) veins (up to several tens of centimetres in thickness) in magnesiocarbonatites filled with these secondary minerals; and (3) breccias of magnesiocarbonatites, with matrixes consisting of minerals of the ancylite assemblage. In all three cases, ancylite, strontianite, and baryte are intergrown and are often cemented by calcite and quartz. In rocks adjacent to ancylite-dominant mineralization, dolomite is pseudomorphically replaced by calcite with abundant Fe-oxide inclusions (Figure 11d). Due to the abundance of inclusions, contains many inclusions of baryte, strontianite, and calcite (Figure 11e).
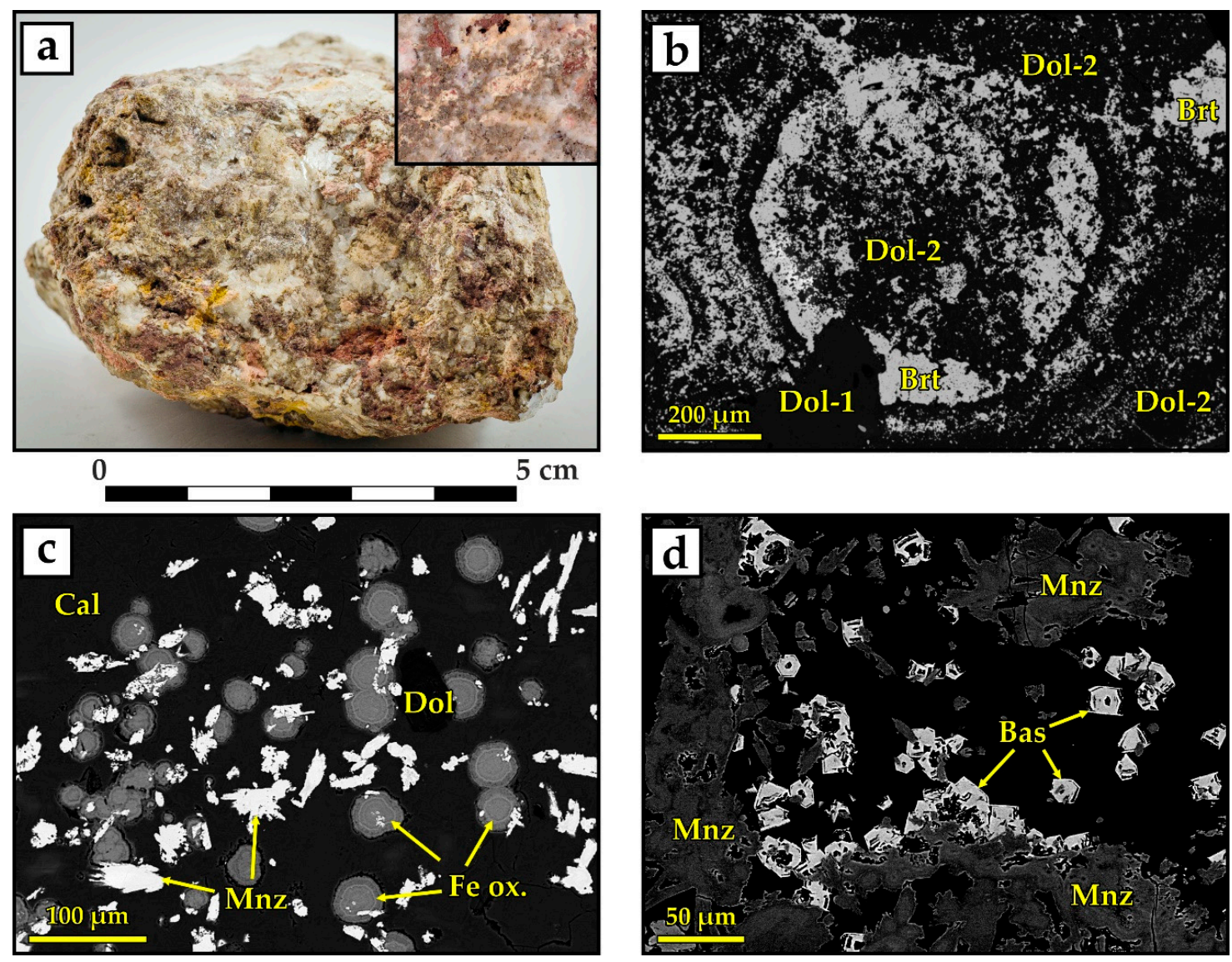

Figure 10. Baryte assemblage. (a) Baryte-dominant magnesiocarbonatite, in the inset photo-a polished section with primary dolomite (light grey), dolomite-baryte dissolution cavities (brown), and late caverns filled with minerals of ancylite and strontianite assemblages (red and light pink). (b) Collomorphic texture composed of baryte and secondary dolomite Dol-2. (c) Collomorphic texture of iron oxides and hydroxides and sheaves of monazite crystals. (d) Euhedral bastnäsite crystals at the edges of a colloform monazite. Photomicrographs (b-d) are in the backscattered electrons (BSE). 

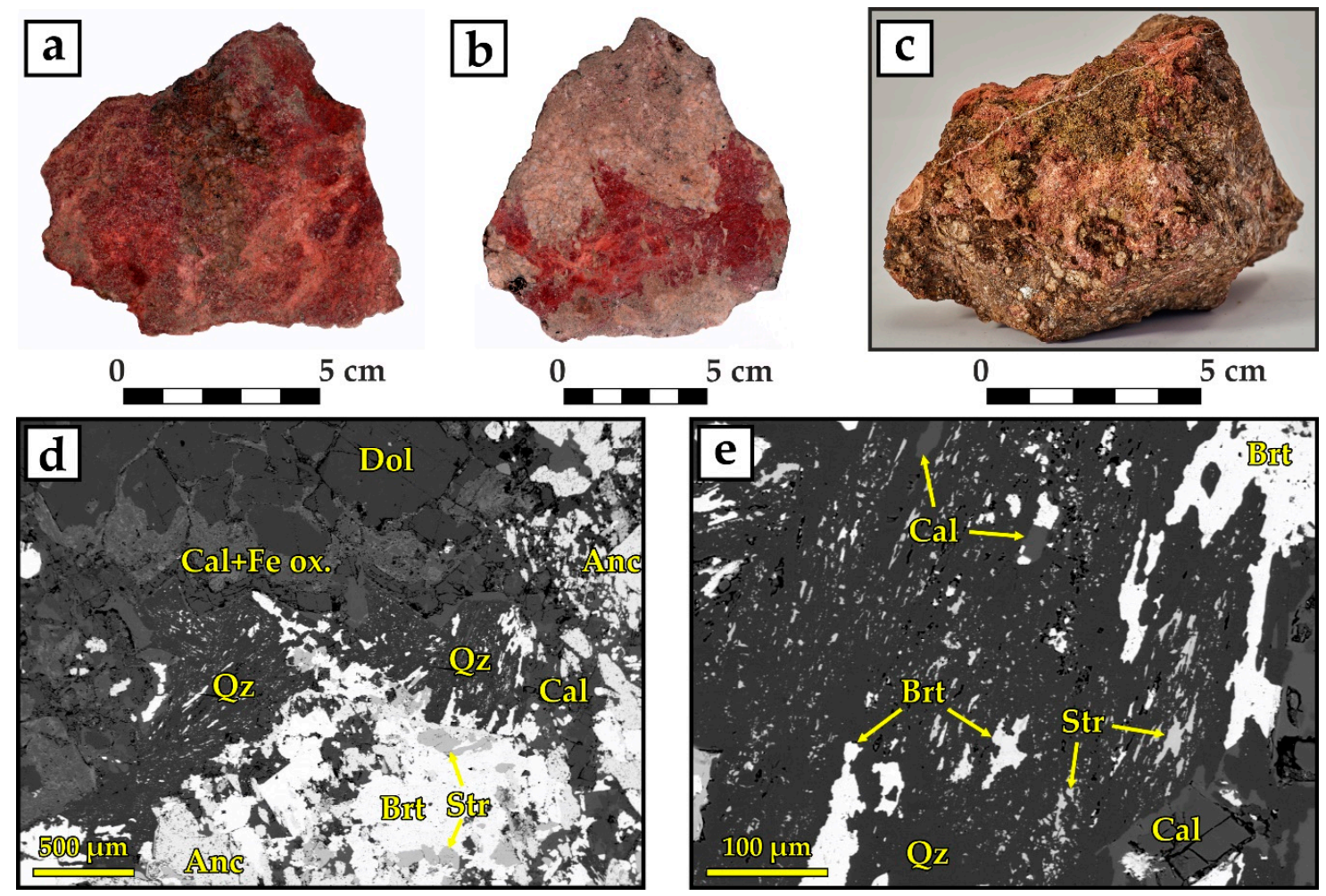

Figure 11. Ancylite assemblage. (a) Dissolution cavity in magnesiocarbonatite with minerals of the ancylite assemblage in place of primary dolomite. (b) Magnesiocarbonatite (grey) dissected by the vein with minerals of the ancylite assemblage (red). (c) Magnesiocarbonatite breccia with a matrix of minerals of the ancylite assemblage. (d) Dissolution cavity with intergrowths of strontianite, baryte, and ancylite in the late pore-filling quartz and calcite; dolomite in contact with the dissolution cavity is replaced by calcite with Fe-hydroxide inclusions. (e) Quartz-baryte-strontianite intergrowths. Photomicrographs (d,e) are BSE images.

The accessory phases in this assemblage are bastnäsite, synchysite, monazite, and thorite. Several bastnäsite morphologies were detected. First, peculiar randomly orientated bastnäsite laths and/or tabular bastnäsite syntaxial intergrowths with synchysite occur in late pore-filling quartz and calcite surrounding ancylite-baryte-strontianite aggregates (Figure 12a). Similar syntaxial intergrowths of REE fluorocarbonates occur in many other carbonatite complexes (e.g., [12,14,48,78,80,108]). These intergrowths are commonly interpreted as the results of $\mathrm{Ca}^{2+}$ and $\mathrm{CO}_{3}{ }^{2-}$ activity changes during mineral formation. Second, we observed the local pseudomorphic replacement of ancylite with anhedral aggregates of bastnäsite (Figure 12b). A similar replacement was found, for example, in carbonatites of Wicheeda, Canada [14] (Figure 7b). Third, small cavities often contain fibroradial bastnäsite aggregates (Figure 12c), which are also common for REE carbonatites worldwide (e.g., [45,68,71,108,109]). Along with monazite and thorite, bastnäsite is one of the latest minerals of the ancylite assemblage. Monazite is chemically similar to the monazite in high-Ti carbonatites and associated with trace thorite (Figure 12d). In the Petyayan-Vara field, thorite is rich in REE (1.5-1.7 wt. \% $\mathrm{Ce}_{2} \mathrm{O}_{3}, 1.5-2.0$ wt. $\% \mathrm{Nd}_{2} \mathrm{O}_{3}$, 1.4-1.7 wt. $\% \mathrm{Sm}_{2} \mathrm{O}_{3}, 1.8-2.8$ wt. $\% \mathrm{Gd}_{2} \mathrm{O}_{3}, 1.2-2.8$ wt. $\% \mathrm{Y}_{2} \mathrm{O}_{3}$ ), and $\mathrm{P}_{2} \mathrm{O}_{5}$ (1.3-3.6 wt. \%). Fe-oxides have overgrown many primary minerals or fully replaced them. The most pronounced replacement by Fe-oxides is manifested in ancylite grains (see Figure 12c,d). Occasionally, HREE-rich thorite cores are found inside Fe-oxide aggregates (Figure 12e). 

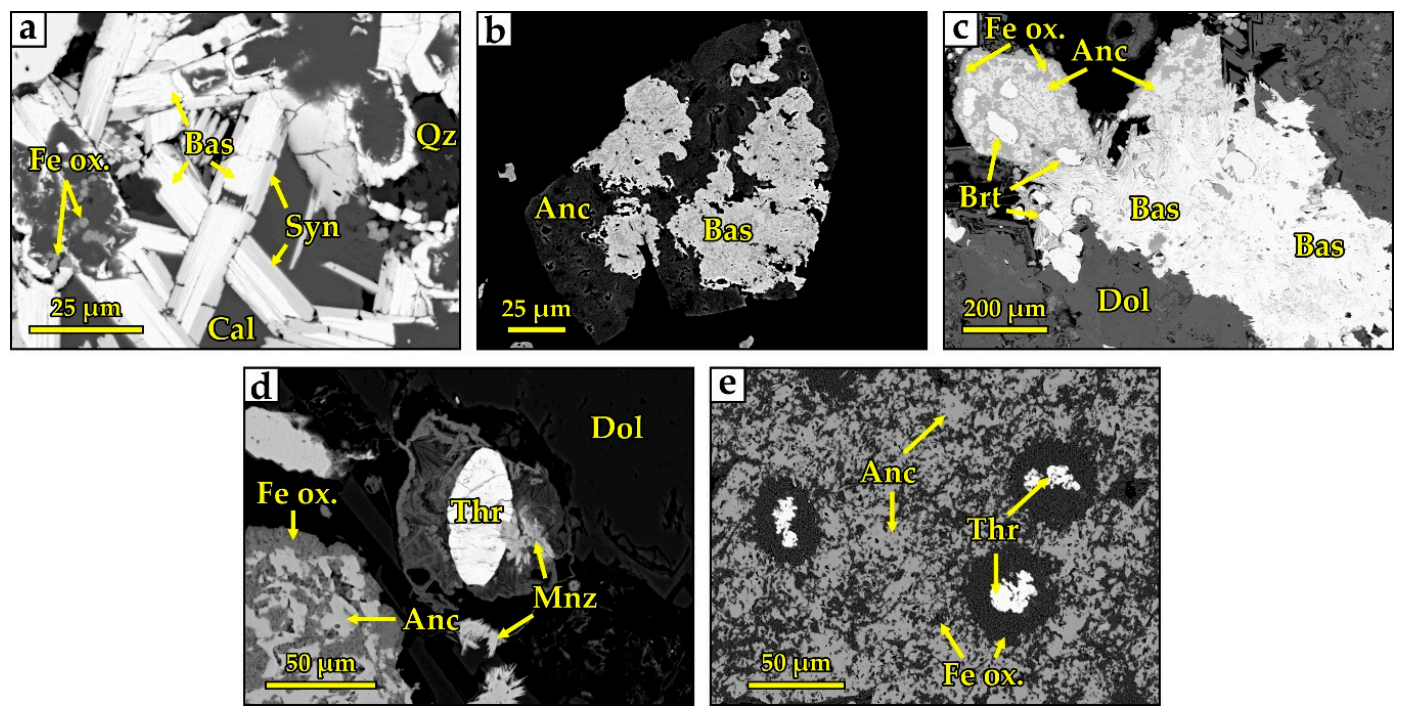

Figure 12. Accessory minerals of ancylite-bearing carbonatites. (a) Bastnäsite laths and tabular syntaxial intergrowths of bastnäsite (white) with synchysite (light gray) in late pore-filling quartz and calcite (dark gray). (b) Ancylite, pseudomorphically replaced by anhedral aggregates of bastnäsite. (c) The cavity, filled by fibroradial bastnäsite aggregates and grains of baryte, ancylite, and iron oxides. (d) Monazite in association with thorite. (e) HREE-rich thorite inside Fe-oxides. All photomicrographs are BSE images.

The main minerals of the strontianite assemblage are milky-white strontianite and calcite. These minerals occupy centimeter-scale veins and lenses and lenses that intersect the magnesiocarbonatites with a red ancylite mixture (Figure 13a). Near these veins, the polymineral pseudomorphs of the least altered magnesiocarbonatites have reduced baryte content and a higher abundance of quartz and bastnäsite (Figure 13b). In bastnäsite, the amount of F gradually decreases from core to rim. The rims usually consist of hydroxylbastnäsite (see the inset in Figure 13b).

In proximity to the baryte and ancylite assemblages and strontianite veinlets, dolomite has elevated contents of Fe and $\mathrm{Mn}$, including the occurrences of ankerite $\left(A n k_{91} \mathrm{Dol}_{8} \mathrm{Kut}_{1}\right)$ and kutnohorite $\left(\mathrm{Kut}_{48} \mathrm{Dol}_{46} A n k_{6}\right)$. A similar increase of the $\mathrm{Fe}$ and Mn contents in the dolomite of late carbonatites was described for the Sallanlatva massif [110], located $25 \mathrm{~km}$ to the west of the Vuoriyarvi massif.

\subsubsection{Late Calciocarbonatites}

At sites proximal to the magnesiocarbonatites with abundant ancylite mineralization, giant-grained monomineralic calcite veins are typical. Macroscopically, these veins are distinguishable by their beige-pale brown colours (Figure 13c). In the exocontacts of these veins, magnesiocarbonatites are brecciated and ferruginated. Calcite veins have rhombic dolomite inclusions coated with hydroxide films and fragments of the host rocks (Figure 13d).

With the exception of calcite from giant-grained calcite veins, several generations of calcite are precipitated during the final stages of secondary mineralization. This late calcite occurs as anhedral grains filling the voids in open fractures and/or dissolution cavities encrusted with minerals of all other assemblages (see Sections 4.1.2 and 4.1.3). 

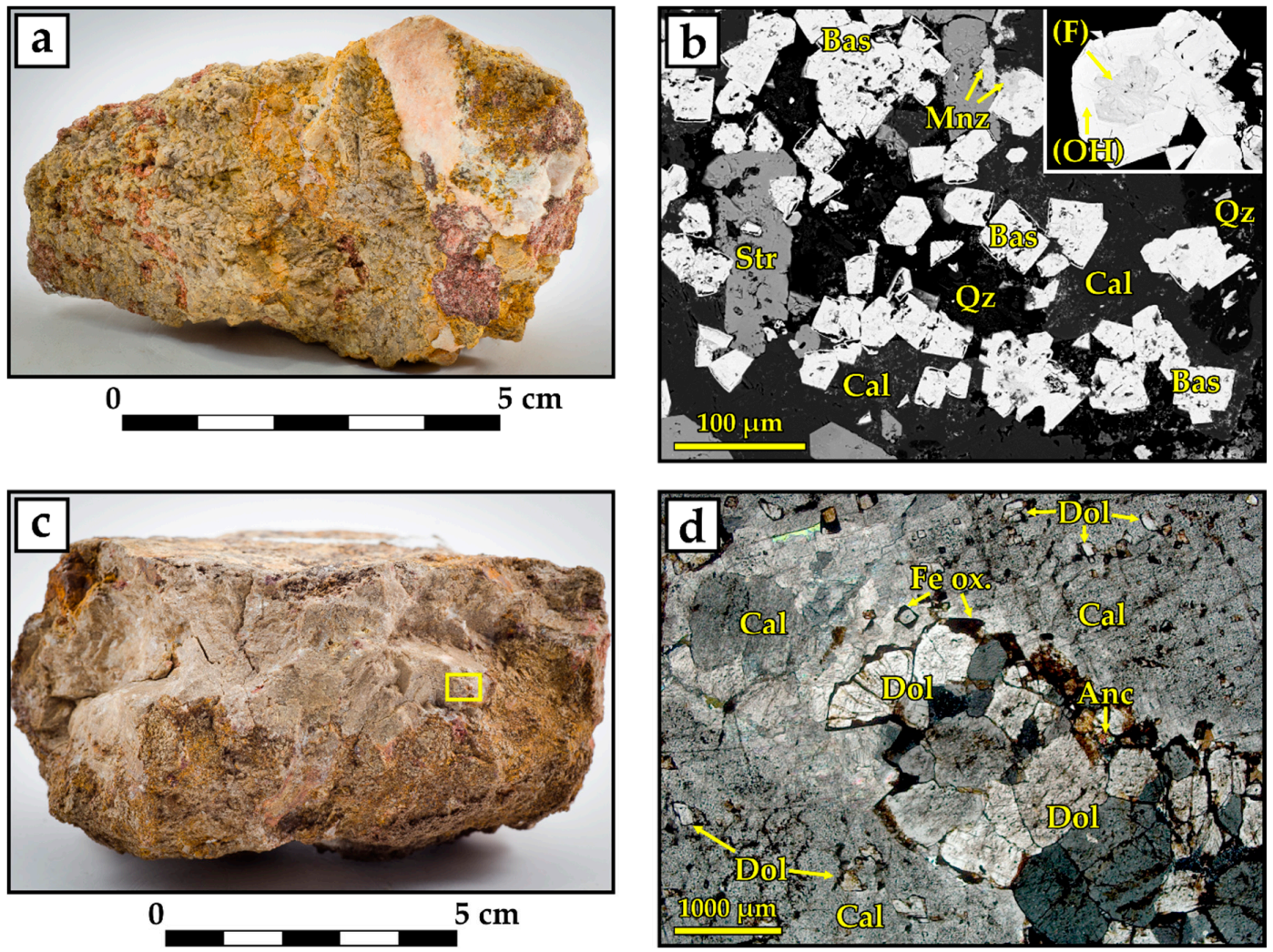

Figure 13. (a) Calcite-strontianite veinlets (pinkish-white), crossing the ancylite-bearing magnesiocarbonatite with pseudomorphs after burbankite (dark red segregations on the right side of the sample). (b) Polished section of the pseudomorph, composed of calcite, strontianite, baryte, monazite, quartz, and zoned bastnäsite; the inset shows a bastnäsite $(\mathrm{F})$ core with a hydroxylbastnäsite $(\mathrm{OH})$ rim. (c) A fragment of a gigantic-grained calcite vein from the margin of ancylite-bearing carbonatite. (d) Vein selvage (yellow rectangle in photo c) with fragments of the enclosing magnesiocarbonatites and separate dolomite inclusions in the gigantic-grained calcite. Photomicrographs (b) under backscattered electrons (BSE images) and (d) transmitted cross-polarized light.

\subsubsection{Magnesiocarbonatite Breccias with REE and Silicate Mineral Matrix}

Locally, the Petyayan-Vara carbonatite bodies contain brecciated magnesiocarbonatites with rare earth and silicate mineral matrixes, texturally similar to those with baryte-strontianite-ancylite matrixes (cf. Figures 11c and 14a). The total REE concentrations of these breccias reaches $4.5 \mathrm{wt} . \%$. The rare earth-silicate groundmass consists of semi-spherical aggregates of lamellar thorium-rich (up to $1.6 \mathrm{wt}$. \% Th) bastnäsite (mainly hydrated), surrounded by cockades of pectinate quartz (Figure 14b,c). Our observations suggest that during fluid interactions with baryte-strontianite-ancylite mineralization, baryte, and strontianite remained stable, and ancylite was completely replaced by bastnäsite (Figure 14d). The association of bastnäsite and/or the related REE fluorocarbonates (synchysite, parisite, röntgenite) with quartz, baryte, and/or strontianite is common in other rare earth carbonatites (e.g., $[13,18,62,108,109,111-113])$. This style of mineralization is one of the most important REE ore types, while ancylite rocks are less commonly ore grade $[57,68]$, and the ancylite-quartz association is extremely rare. The dolomite fragments in the breccias were repeatedly overgrown by later dolomite generations (Figure 14e). The early dolomite is Dol-1 from high-Ti rocks both morphologically (porous) and chemically $(9 \pm 2 \mathrm{~mol}$. \% Ank, $2 \pm 1 \mathrm{~mol}$. \% Kut, without Sr). The surrounding rims of dolomite Dol-2, optically turbid from the many inclusions of Fe-oxides, are chemically ( $4 \pm 2$ mol. \% Ank, $2 \pm 1$ mol. \% Kut) similar to dolomite Dol-2 from the other carbonatite varieties of the Petyayan-Vara. The needles and films of Fe oxides/hydroxides were formed on the surfaces of Dol-2 (see Figure 14e). The latest dolomite overgrowths (Dol-3) are oscillatory zoned in the 
BSE-images due to their Fe/Mg contents and non-porous and optically clear properties. Dol-3 is rich in Fe $(14 \pm 5$ mol. \% Ank), very poor in $\mathrm{Mn}(<1 \mathrm{~mol}$. \% Kut $)$, and free of Sr.
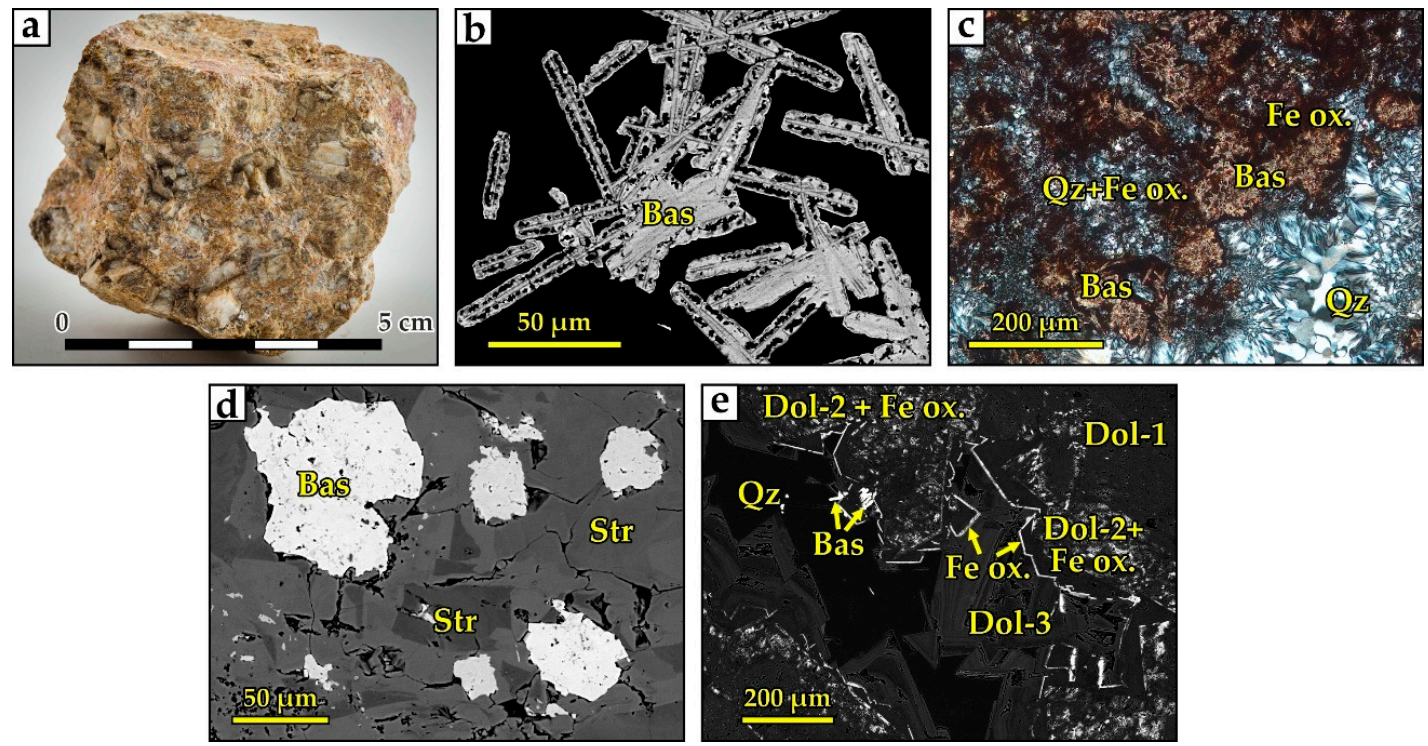

Figure 14. (a) A sample of a magnesiocarbonatite breccia with a quartz-bastnäsite matrix. (b) Crystals of bastnäsite. (c) Bastnäsite, surrounded by quartz. (d) Bastnäsite pseudomorphs after ancylite. (e) Spongy dolomite Dol-1 from the breccias, with rims of Dol-2 and inclusions of iron oxides, overgrown by the zoned dolomite Dol-3. Photomicrographs (b), (d), (e) in backscattered electrons (BSE images) and (c) in transmitted cross-polarized light.

\subsection{6. "Hybrid Rocks" and the Mineral Paragenesis}

In addition to the rocks discussed above, "hybrid" carbonatites occur in the Petyaian-Vara field. In these rocks, the mineral associations described in Sections 4.1.1-4.1.5 are superimposed on each other in various combinations. Therefore, hybrid carbonatites record mineral paragenesis. For example, sample 15K-12.0 (Figure 15a,b) contains minerals and textures representative of most assemblages of the Petyayan-Vara carbonatites (in the formation sequence):

1. Sharp-angled fragments (30-40\% of the rock volume) composed of spongy dolomite Dol- 0 and Dol-1 with zoned Dol-2 rims. Dol-2 includes idiomorphic crystals of brookite (Figure 15c). These are characteristic of high-Ti carbonatite;

2. In the space between the dolomite fragments separated by brecciation, minerals were deposited in several stages. The earliest mineral is baryte, representing the assemblage of baryte-dominant carbonatites. Baryte is not as idiomorphic as dolomite (Figure 15c) but is more euhedral than all other minerals;

3. After baryte and dolomite, euhedral crystals of irregular polygonal and rhombic shapes were crystallized (Figure 15e). This morphology is characteristic of ancylite from the studied carbonatites. Ancylite crystals correspond to the formation stages of ancylite-dominant carbonatites. A detailed study of these crystals showed that they represent pseudomorphs consisting of anhedral bastnäsite fragments inside a matrix of intergrown ancylite and quartz (Figure 15f). Inclusions of ancylite and strontianite also occur in bastnäsite;

4. Fine crystalline quartz occupies the most remaining space. It contains spongy grains (Figure $15 \mathrm{~g}$ ) and clusters of bastnäsite needles (Figure 15h). These minerals correspond to the mineral assemblage of breccias with a REE and silicate mineral matrix; 
5. On the walls of the cavities that remained after the quartz deposition, quartz crystals with well-crystallized tips were formed (Figure 15i). In the final stage, all remaining empty space was filled with strontianite assemblage.

These observations combined with our data obtained for other carbonatite varieties of the Petyayan-Vara suggest a paragenetic sequence similar to that for the Bear Lodge carbonatites ([72]; cf. their Table 1 and our Figure 16) and others of the Kola Peninsula ([78] and references therein).
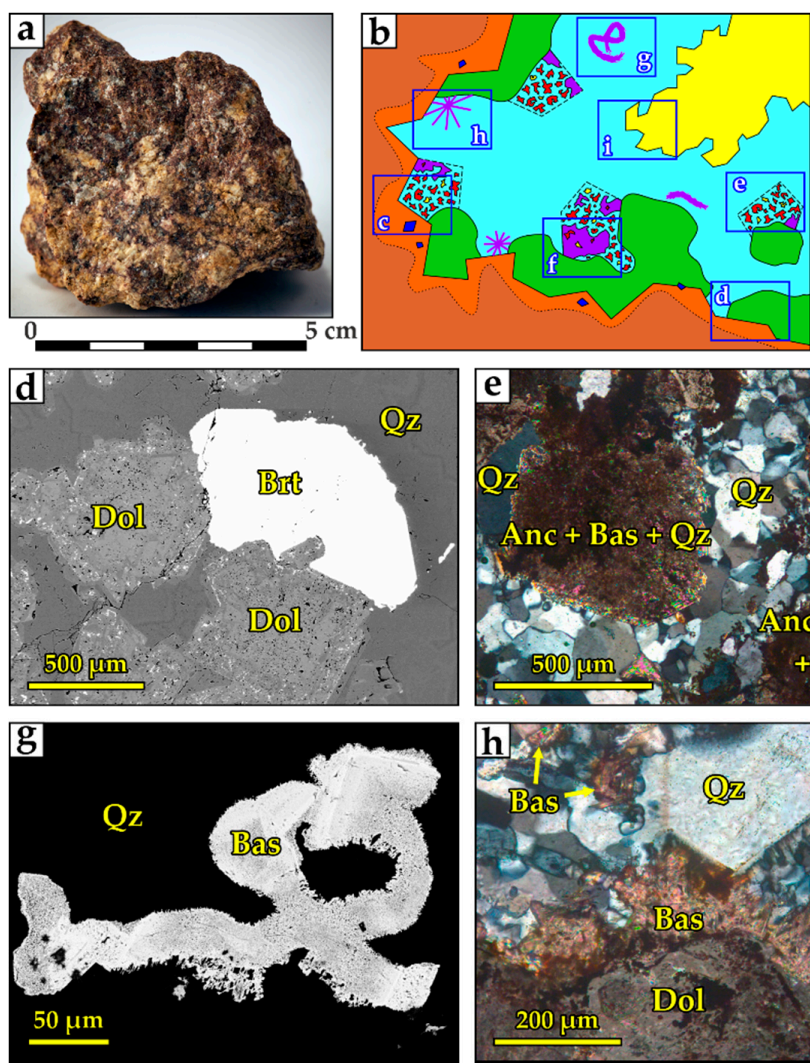
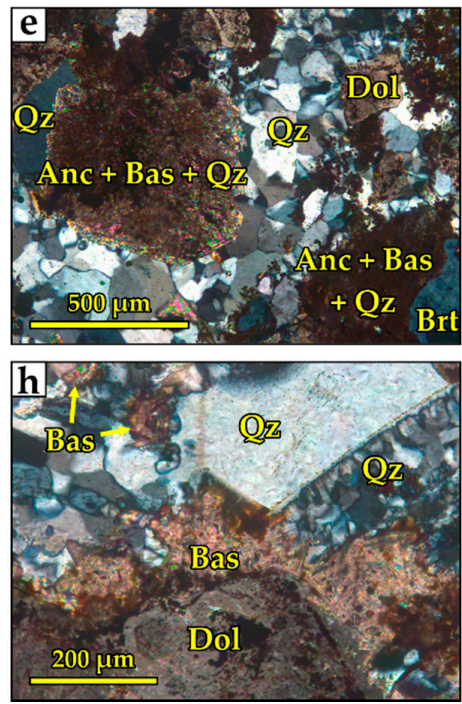
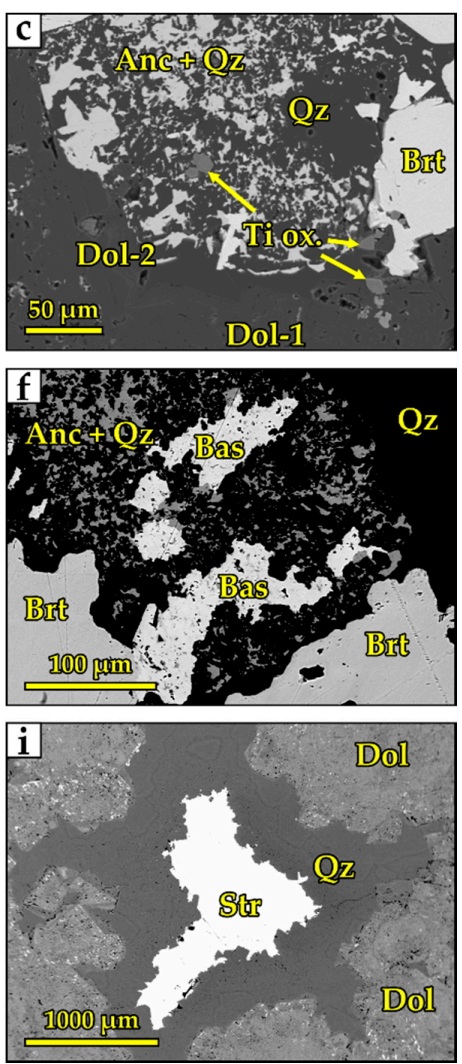

Figure 15. (a) A sample of "hybrid" carbonatite. (b) A sketch comprising the typical location of the mineral assemblages in the rock texture (c) to (i). (c) Ti-oxides in Dol-2. (d) Baryte overgrowing dolomite. (e) Pseudomorphically replaced ancylite. (f) Anatomy of pseudomorphs after ancylite. (g) Spongy bastnäsite. (h) A cluster of bastnäsite needles. (i) A cavity in quartz filled with strontianite. Photomicrographs (e,f) in transmitted cross-polarized light; all others-BSE images. 


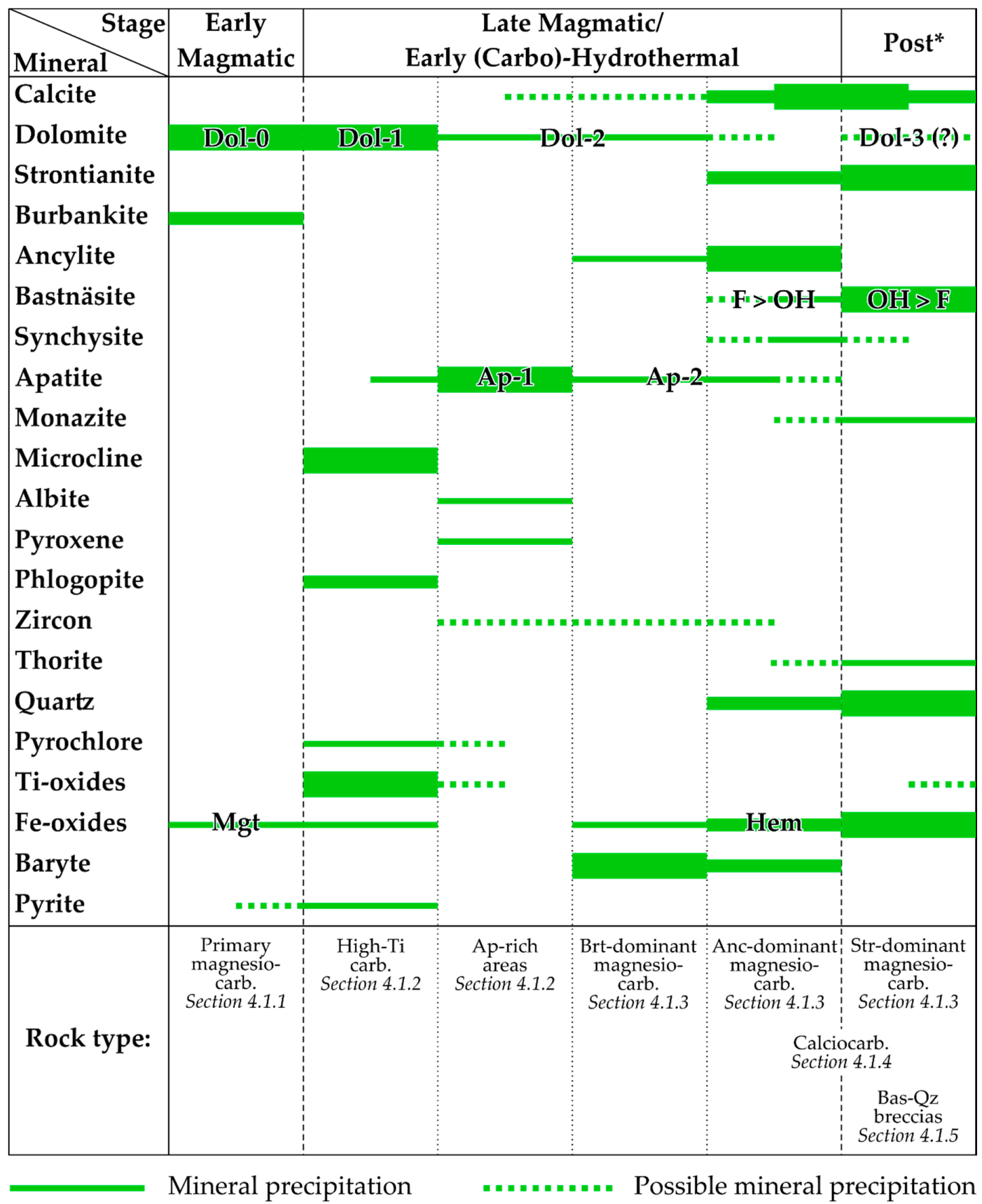

Figure 16. The proposed paragenetic sequence of minerals in the Petyayan-Vara carbonatites. Note: Post* includes both late (carbo)-hydrothermal and supergene stages. Line thickness indicates deposition intensity.

\subsection{Geochemistry}

The chemical differences among the Petyayan-Vara carbonatites are illustrated by the primitive mantle- and chondrite-normalized plots (Figure 17a,b). 

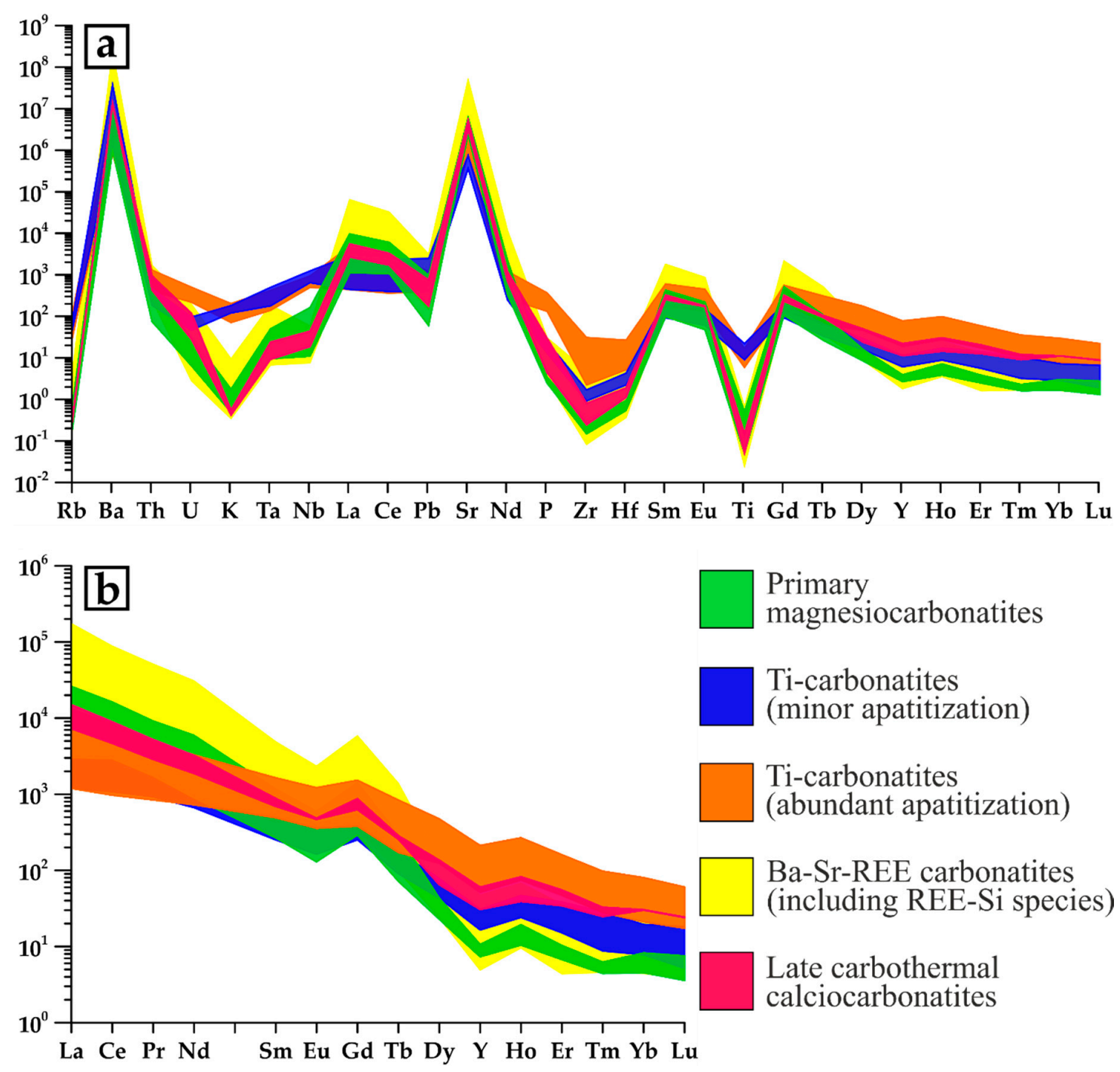

Primary magnesiocarbonatites

Ti-carbonatites (minor apatitization)

Ti-carbonatites (abundant apatitization)

Ba-Sr-REE carbonatites (including REE-Si species)

Figure 17. (a) Primitive mantle- and (b) chondrite-normalized plots for carbonatites of the Petyayan-Vara field. Normalization values from [114].

All carbonatites of the Petyayan-Vara are rich in Ba and Sr. High-Ti carbonatites are distinguished from other varieties by higher contents of $\mathrm{K}, \mathrm{Ti}, \mathrm{Nb}$, and $\mathrm{Ta}$ (as well as $\mathrm{Al}, \mathrm{Si}$, and $\mathrm{Fe}$ ) due to the abundance of potassium feldspar, phlogopite, and titanium oxides. Apatite-bearing high-Ti carbonatites are additionally enriched with $\mathrm{P}, \mathrm{Zr}, \mathrm{Hf}, \mathrm{U}$, and HREE. The least altered magnesiocarbonatites have $\mathrm{La}_{C N} / \mathrm{Yb}_{C N}$ of 670 to 3170 and total REE contents of $0.32-2.03$ wt. \%. High-Ti carbonatites and their apatite-rich areas have low $\mathrm{La}_{C N} / \mathrm{Yb}_{C N}$ ratios (60-330 and 20-160, respectively) and low REE contents (0.15-0.74 wt. \% and 0.18-1.14 wt. \% total REE, respectively). Ba-Sr-REE carbonatites (including brecciated magnesiocarbonatites with quartz-bastnäsite matrix) are characterized by highly fractionated REE distributions $\left(\mathrm{La}_{\mathrm{CN}} / \mathrm{Yb}_{\mathrm{CN}}=1200-7600\right)$ with a maximum REE content of 5-11 wt. \%. For ancylite-dominant rocks, the $\mathrm{La}_{C N} / \mathrm{Yb}_{\mathrm{CN}}$ ratios are the highest (more than 6000), and the total REE content is more than $10 \mathrm{wt}$. \%. Brecciated magnesiocarbonatites with quartz-bastnäsite matrix have $\mathrm{La}_{C N} / \mathrm{Yb}_{\mathrm{CN}}$ of 1500-2700. Calciocarbonatites are characterized by low REE contents (0.60-1.14 wt. \%) and average $\mathrm{La}_{C N} / \mathrm{Yb}_{C N}$ ratios (240-500). There is a positive correlation between the $\mathrm{La}_{C N} / \mathrm{Yb}_{C N}$ ratios and total REE content. The $\mathrm{La}_{C N} / \mathrm{Yb}_{C N}$ ratio is closely related to the mineral composition. Low $\mathrm{La}_{C N} / \mathrm{Yb}_{C N}$ values are characteristic of rocks in which HREE-apatite Ap-2 is present. High LaCN $/ \mathrm{Yb}_{C N}$ values were calculated for rocks with bastnäsite and (higher) with ancylite-i.e., with minerals containing mainly LREE. The only independent REE host mineral in calciocarbonatites is ancylite, 
trapped with wall rock fragments. Studies of the Aley complex (British Columbia, Canada) and the Bear Lodge complex (USA) have shown that calcite in hydrothermal carbonatites usually has a flat REE distribution spectrum [115]. The contribution of REE from calcite is likely responsible for the decreased $\mathrm{La}_{\mathrm{CN}} / \mathrm{Yb}_{\mathrm{CN}}$ values for calciocarbonatites.

The interrelationships of element concentrations in the studied rocks were analyzed using factor analysis. The basic principles of this method are available in [116,117]. The analytical dataset of all carbonatite varieties from the Petyayan-Vara field (43 samples), comprising the contents of major and trace elements (Table S1), was subjected to a factor analysis in its R-modification ("by variables"). Factors were extracted by the method of principal components without subsequent rotation. The two major (in terms of weight) factors are:

$$
\begin{gathered}
F-I_{28}=\frac{C_{66} M g_{53} M n_{53} B a_{52} S_{51} L a-G d_{34-41} S r_{37}}{K_{80} R b_{80} A l_{79} U_{78} D y-L u_{64-78} F e_{76}^{3+} V_{75} F e_{74}^{T} P_{72} F_{71} Y_{71} T i_{71} Z r_{71} H f_{71} S i_{66} C_{59} T a_{59} N a_{52} N b_{51} L i_{50} C r_{46} C s_{38}}, \\
F-I I_{19}=\frac{L a-T b_{81-96} S r_{70} D y-L u_{41-65} T h_{55} Y_{51} P_{41} U_{38} Z r_{37} H f_{35} F_{30}}{F e_{43}^{2+} M g_{42} M n_{35} C r_{32}},
\end{gathered}
$$

where the subscript at factor $(F)$ is the fraction of the total variance explained by the factor (in \%), and the subscript at the element is its loading on the factor multiplied by 100. The numerator contains elements that directly correlate with the factor, and the denominator includes elements with inverse correlation. Only elements with significant factor loadings are shown (the correlation is insignificant at $\mathrm{r}<\left|\mathrm{r}_{\text {crit }}\right|$; for $n=43$, the critical value module $\mathrm{r}_{\text {crit }}$ is 0.30 at a significance level of $p=0.05$ ). On the factor plane determined by these factors, the figurative points of the elements shape the fields that reflect the chemical specificity of the Petyayan-Vara carbonatites (Figure 18).

In order to provide a mineralogical meaning to the geochemical variables, the technique outlined by [118] was used. As demonstrated by this study, in most cases, each component is concentrated primarily in one or two minerals. For example, almost all $\mathrm{Ti}, \mathrm{Nb}$, and $\mathrm{Ta}$ are in titanium oxides; apatite hosts $\mathrm{P}$, HREE, and, along with phlogopite, F; zircon contains all $\mathrm{Zr}$ and Hf; apatite and bastnäsite take a leading role in the distribution of Th; ancylite and strontianite incorporate most Sr; almost the entire volume of LREE is concentrated in ancylite and, to a lesser extent, in bastnäsite.

The considered factors distinguish the main mineral assemblages in Figure 18. The fields of the mineral assemblages overlap in only two cases: (1) When a common mineral is present in two assemblages, e.g., baryte found in both unaltered and Ba-Sr-REE carbonatites; and (2) when an element is present in two or more minerals from different assemblages, e.g., Th contained in both apatite and bastnäsite (the apatite and Ba-Sr-REE assemblages, respectively). The figurative points of such "common" components are shifted towards one of the axes. That is, by virtue of this "commonality", the factor corresponding to the orthogonal axis cannot indicate which of the assemblages to attribute to the element. This is especially important for calcium points, which are displaced to the intersection of the axes due to calcite's involvement in virtually all the identified mineral assemblages.

The first factor separated high-Ti carbonatites from all others. The values of the factor loading indicate that the formation process of high-Ti rocks was accompanied by an increase in $\mathrm{K}, \mathrm{Na}, \mathrm{Al}, \mathrm{Si}$, and the entire spectrum of HFSE (specifically Ti, Nb, Ta, Zr, and Hf). The second factor reflects the processes related to the accumulation of rare-earth elements (REEs). These processes are (1) phosphorus addition to the high-Ti rocks, accompanied by abundant apatite crystallization (hereafter, "apatitization") and (2) Ba-Sr-REE mineralization of the magnesiocarbonatites. Heavy rare earth elements (Y, Dy-Lu) are precipitated mainly during the first process, and light rare earth elements (La-Gd) are precipitated during the second process. Apatitization was also accompanied by a separation of HFSE: Ti, Nb, and Ta are concentrated in high-Ti carbonatites, while $\mathrm{Zr}$ and $\mathrm{Hf}$ are concentrated only in the apatite-rich sites of these rocks. Notably, the correlation coefficients between the concentration of $\mathrm{P}_{2} \mathrm{O}_{5}$ and the concentrations of $\mathrm{Zr}, \mathrm{Hf}$, and HREE are high (from 0.85 to 0.93 at $n=43$ ). 


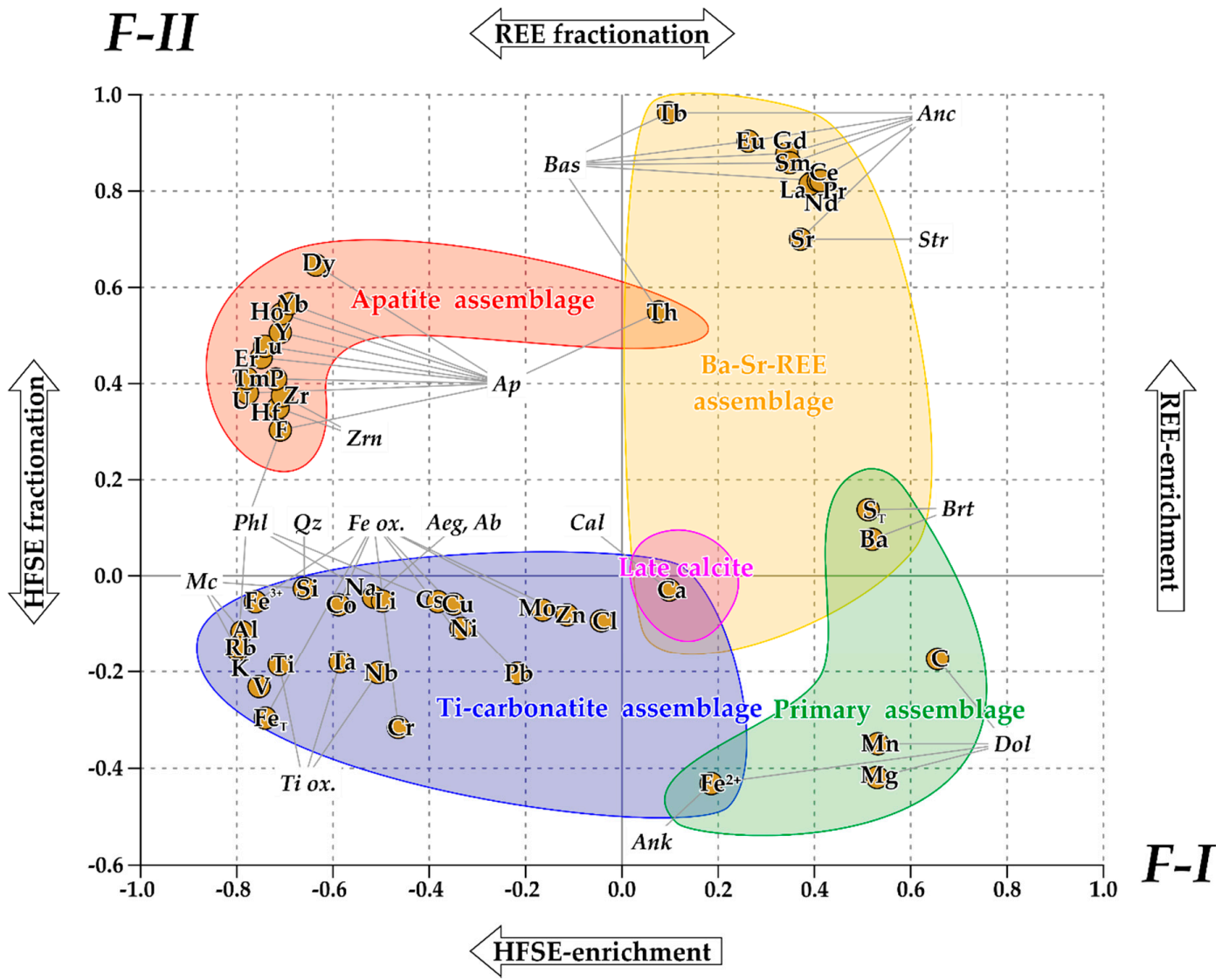

Figure 18. Points of the studied major and trace elements on the factor plane formed by the two factors with maximum eigenvalues. The colored fields distinguish the groups of elements associated with certain minerals from one or other mineral assemblages. Illustration is based on the work of [118].

We note that factor analysis was carried out at the early stage of the study (before petrographic and mineralogical investigations). Two data sets were subjected to statistical processing: (1) chemical compositions of rock samples (major and trace elements) and (2) a combined selection of chemical compositions and X-ray diffraction patterns. Factor analysis of a set of chemical compositions revealed groups of elements similarly distributed in the rocks (Figure 18). The projection of samples onto this factor plane yielded the first classification of carbonatites. Thus, the statistical data processing of a combination of chemical compositions and X-ray diffraction patterns provides the following advantages: (1) simplified determination of minerals, (2) revealing the effect of an identified mineral on the distribution of each element, and (3) tracing the connection between results of the statistical processing of geochemical data and minerals/mineral assemblages (Figure 18, the relationship between elements and minerals) [118]. The detailed petrographic study presented in this work fully confirmed the results obtained using statistical methods. This shows the high efficiency of the described statistical approaches for the study of such complex geological objects as late carbonatites.

\section{Discussion}

\subsection{The Protolith of Carbonatites of the Petyayan-Vara Field}

Except for the Petyayan-Vara field, in all parts of the Vuoriyarvi massif, the most common primary carbonatites are calciocarbonatites. It is believed that magnesiocarbonatites, which dominate in the Petyayan-Vara field, are more mature products of magmatic differentiation than calciocarbonatites [119]. Consequently, the Petyayan-Vara magnesiocarbonatites were localized in the most highly evolved part of the Vuoriyarvi complex. 
The magnesiocarbonatites with minor baryte and hexagonal polymineral pseudomorphs (consisting of REE-carbonates, baryte, and strontianite; see Section 4.1.1) are only slightly metasomatically altered and are probably most representative of the least altered carbonatites in the Petyayan-Vara field. The presence of carbocernaite, burbankite, and calcite inclusions in poikilitic dolomite are typical of primary magmatic dolomite ([120], cf. their Figure 5e and our Figure 3d). The polymineral pseudomorphic replacement textures are evidence of alteration. As shown for the various alkaline complexes, such pseudomorphs are usually formed after burbankite [71,78,121], an early syn-magmatic mineral [97]. Thus, the presence of altered burbankite is of interest, because the "early magmatic crystallization of rare earth minerals could be a significant factor in generating high-volume REE deposits" [16].

Magmatic magnesiocarbonatites were protoliths for all other (carbo)-hydrothermal-metasomatic carbonatite varieties. The specific mineralogical and geochemical features (including high concentrations of REE) were produced in these carbonatites during a series of metasomatic events.

\subsection{Formation of HFSE-Rich (High-Ti) Carbonatites}

High-Ti carbonatites are of particular interest due to the discovery of the unique Morro dos Seis Lagos Ti-Nb-REE deposit (Brazil) [11], wherein Ti-oxides are the main hosts of Nb. High-Ti carbonatites are reported at Magnet Cove (USA) [91], Gross Brukkaros (Namibia) [92], and Salpeterkop (South Africa) [93]. In terms of mineral associations, the high-Ti carbonatites of the Petyayan-Vara are akin to the "classical" rødbergites of the Fen massif $[58,88]$. However, there are some minor differences. First, in contrast to rødbergites, feldspars and mica from high-Ti carbonatites of the Petyayan-Vara do not contain barium, and baryte is minor. Second, unlike high-Ti carbonatites, rødbergites of the Fen massif lack titanium oxides. High-Ti carbonatites may represent specific varieties of rødbergites, but the mechanism of their formation and the source of their enrichment in the HFSE are not completely clear.

At present, we cannot state that magnesiocarbonatites were the only protolith of high-Ti carbonatites of the Petyayan-Vara field. Titaniferous carbonatites could possibly have formed by the (auto) metasomatism of earlier carbonatites of a different variety (not magnesiocarbonatite). Nonetheless, the formation of high-Ti carbonatites was obviously controlled by the influence from an additional portion of a fluid or fluid-saturated melt.

Geochemically, high-Ti carbonatites of the Petyayan-Vara are unusual for carbonatites. Commonly, carbonatites contain minor amounts of $\mathrm{K}, \mathrm{Al}, \mathrm{Si}$, and Ti. According to the results of the study of natural materials [122] and the experimental data [123-126], the low contents of the indicated elements are caused by their partitioning into the silicate part during immiscible separation of carbonatite and silicate melt. Moreover, the crystallization of alkaline feldspars, which are widespread in high-Ti carbonatites, requires abnormally high (for carbonatite melts) $\mathrm{SiO}_{2}$ activity $[9,127]$. This high $\mathrm{SiO}_{2}$ activity is explained by assimilation and/or by superimposed hydrothermal alteration $[9,127,128]$. This is consistent with the data on $\mathrm{Sr}$ and Nd isotope systems in silicocarbonatites [129]. General ideas on the nature of high-Ti carbonatites correspond to the above-mentioned hypotheses.

The source of titanium (as well as $\mathrm{K}, \mathrm{Al}$, and $\mathrm{Si}$ ) could be a specific residual silicate-carbonatite melt and/or fluid. The presence of Ti-rich fluorophlogopite and fluorocalciopyrochlore in high-Ti carbonatites of the Petyayan-Vara field indicates that the source was rich in fluorine. According to reports on the partitioning of elements between silicate melts and immiscible fluoride, chloride, carbonate, phosphate, and sulfate melts [125], this type of residual melt most likely accumulated HFSE, including titanium. An alternative source of $\mathrm{Ti}, \mathrm{K}, \mathrm{Al}$, and $\mathrm{Si}$ could be melt-assimilated or fluid-remobilized silicate rock (s). For example, Kapustin [130] established a compositional relationship between carbonatites and associated aluminosilicate rocks, concluding that Ti and several other elements could be assimilated from host rocks. However, in the Petyayan-Vara field, the assimilation of wall rock material seems to be improbable. The pyroxenites hosting carbonatites are almost free of $\mathrm{Al}$ and $\mathrm{K} . \mathrm{Na}$, which is abundant in pyroxenites, is absent in high-Ti carbonatites. Hypothetically, the neighbouring gneisses could also have been assimilated by carbonatite melts deeper in the complex, increasing $\mathrm{Al}$ and Si concentrations. As shown in [131], contamination of the kimberlite melt with 
crustal components results in the appearance of a Ti-rich potassium-aluminosilicate melt, captured as the inclusions in diamonds. Ti-rich melts of similar compositions were obtained in experiments modelling the melting of carbonatized pelites [132].

\subsection{Connection between the Local HREE Enrichment and Apatitization}

In general, the REE content in high-Ti carbonatites is relatively low (up to $1.1 \mathrm{wt}$. \% total REE). However, high-Ti carbonatites and especially their apatite-rich areas are noticeably enriched in HREE compared to all other rocks of the Petyayan-Vara field, including Ba-Sr-REE carbonatites. Late carbonatites with HREE mineralization associated with late-stage hydrothermal phenomena are found in many complexes (e.g., Tundulu, Malawi [80]; Songwe-Hill, Malawi [47]; Bear Lodge, USA [68]; Lesser Qinling, China [34]; Fen, Norway [58]). Researchers have presented several hypotheses for the HREE enrichment of late carbonatites. Possible explanations include HREE enrichment of the primary source, the passive enrichment of minerals due to the selective removal of LREE, and selective LREE or HREE transport by fluids rich in sulfur, phosphorus, chlorine, and/or fluorine. More than one mechanism is possible for the enrichment of late carbonatites with heavy rare earth elements. As a result of these mechanisms, xenotime-(Y) [34,69,133], brockite-(Y) [69], mckelveyite-(Y), ewaldite, donnayite-(Y) [78], and other HREE mineral phases were formed in these rocks. In carbonatites of the Petyayan-Vara and a number of other complexes (e.g., $[47,80,81]$ ), the accumulation of HREE is related to fluorapatite (see Section 4.2).

In the Petyayan-Vara carbonatite field, apatitization occurs in high-Ti carbonatites and the surrounding rocks. However, the early apatite Ap-1, which precipitated either simultaneously or immediately after the primary mineral assemblage of the high-Ti carbonatites, is free of impurities. The activity of both LREE and HREE was thus relatively low during the formation of high-Ti carbonatites. The HREE enrichment of the Petyayan-Vara carbonatites is related to alteration and late-stage apatite crystallization. The morphology of late Ap-2 rich in REE is typical of hydrothermal apatite ([134]; cf. Figure $10 \mathrm{~h}$ therein and Figure $5 \mathrm{c}$ in this contribution). Nevertheless, the solubility of REE in phosphate solutions is low ([135,136] and the references therein). Therefore, phosphate solutions are unlikely transport agents of REE. According to the experimental data, "the main REE transporting ligands are chloride and sulfate, whereas fluoride, carbonate, and phosphate likely play an important role as depositional ligands" [136].

HREE-rich Ap-2 appears to have formed by in situ dissolution of Ap-1 and recrystallization. The chemical composition of Ap-2 (high Sr, REE, and S concentrations) relates it to the minerals of Ba-Sr-REE carbonatites (baryte, strontianite, and REE-carbonates). The high sulfur content in Ap-2 suggests a higher activity of this component during crystallization ([137] and the references therein). Moreover, the fluids controlling the formation of late apatite influenced the dolomite of the protolith in the same way as the fluids, which caused ancylite formation. In both cases, dolomite was pseudomorphically replaced by the calcite hosting many inclusions of Fe oxides (cf. Figures $6 \mathrm{c}$ and 11d). This illustrates the relationship between the HREE-enrichment of high-Ti carbonatites and the stage of alteration which led to the formation of baryte- and ancylite-dominant carbonatites in the Petyayan-Vara field.

We suggest that the mechanism for HREE precipitation was the interaction of orthomagmatic carbonatitic Ba-Sr-REE-S-rich fluid with phosphate-bearing rocks formed simultaneously with high-Ti carbonatites or immediately after them. As a result of exposure to this fluid, dolomite was locally replaced with calcite, the original apatite Ap-1 was partially dissolved and reprecipitated in situ, and Ba-Sr-REE minerals crystallized in cracks and cavities. Most Ba, Sr, and LREEs were removed through the cracks, whereas HREEs were absorbed by the growing Ap-2. A similar enrichment mechanism was described in [138].

The same HREE enrichment mechanism may have occurred in carbonatites of other complexes geochemically similar to those of the Petyayan-Vara. For instance, in the Montviel Carbonatite Complex 
(Abitibi, Canada), the Ba-Sr metasomatic zone with LREE mineralization is separated from the P-F metasomatic zone containing HREE minerals [13].

\subsection{The Main Stage of REE Mineralization (the Formation of Ancylite Ores)}

From an economic standpoint, carbonatites of this field are unique because ancylite is the main REE ore mineral. In most known carbonatite complexes, the principal REE host is bastnäsite (REE-carbonate). Frequently, bastnäsite occurs in association with strontianite (Sr-carbonate). However, despite the abundance of both Sr and REE in late carbonatites, ancylite (REE-Sr-carbonate) forms large accumulations on rare occasions. Unlike bastnäsite [139-141], the physicochemical stability limits of ancylite are not clear. Factors contributing to the accumulation and preservation of economically significant ancylite contents include the following:

1. Since the formation of ancylite is controlled by $a \mathrm{REE}^{3+}, a \mathrm{Ca}^{2+}, a \mathrm{Sr}^{2+}, a \mathrm{Ba}^{2+}, a \mathrm{Na}^{+}, a \mathrm{~F}^{-}[65]$, $a \mathrm{CO}_{3}{ }^{2-}[68,142]$, and $a(\mathrm{OH})^{-}$[78] (where " $a$ " is activity), the most important factor for its deposition is fluid chemistry. Ancylite crystallization is possible at relatively low values of $a \mathrm{REE}^{3+} /\left(a \mathrm{Ca}^{2+}+a \mathrm{Sr}^{2+}+a \mathrm{Ba}^{2+}+a \mathrm{Na}^{+}\right)$(otherwise, carbocernaite is formed [65]), at low values of $a \mathrm{~F}^{-}$(otherwise, cordylite is formed [65]), and at high values of $a \mathrm{CO}_{3}{ }^{2-}$ and $a(\mathrm{OH})^{-}$(otherwise, synchysite and/or bastnäsite is formed [68,78,142]).

2. In many REE deposits, ancylite is replaced by REE-fluorocarbonates. The reverse situation is extremely rare [12,143]. Thus, favorable conditions for ancylite crystallization arise at an early (carbo)-hydrothermal-metasomatic stage.

3. The absence of supergene processes, which often destabilize ancylite. For example, in the Bear Lodge alkaline complex, a clear vertical zonation was discovered [68,71]. Ancylite-strontianitebaryte mineralization occurs in deeper parts of the section and is replaced by REE fluorocarbonates in the shallower oxide zone (100 $\mathrm{m}$ from the surface). Carbonatite samples of the Petyayan-Vara field were collected from the surface, where most of their mineral assemblages are similar to those found only in the deeper parts of the Bear Lodge alkaline complex. The weak influence of supergene alteration on the rocks of the Vuoriyarvi massif is explained by specific aspects of the recent geological history of the Kola region. The Svecofennian shield has undergone several periods of glaciation. Any weathering crusts that may have formed before the latest glaciations were eroded by glacial abrasion. Subsequently, the exposed rocks were protected from aggressive chemical weathering by the subarctic climate. This facilitated the preservation of ancylite ores in the near-surface parts of the Vuoriyarvi massif.

As mentioned above, chloride and sulfate are considered to be the main ligands for REE transport in hydrothermal fluids (e.g., [14,62,144-146]). We suggest that the Ba-Sr-REE-rich sulfate (+Cl?) fluid played an important role in the transport of REE within the Petyayan-Vara field.

Baryte-ancylite assemblages seem to offer reliable evidence for the correlation between REE enrichment and the involvement of sulfur in the system. Probably carbonatites of Petyayan-Vara derived from a specific sulfur-rich source, similar to that described in the West Transbaikalia carbonatite province [79]. A large baryte deposit (244.5 million tons of ore with $11-14 \mathrm{wt} . \%$ of $\mathrm{BaSO}_{4}$ and $0.4 \mathrm{wt}$. \% of $\mathrm{REE}_{2} \mathrm{O}_{3}$, [83]) of the Sallanlatva carbonatite complex is located approximately $20 \mathrm{~km}$ to the west of the Vuoriyarvi massif. Thus, some sulfur-rich sources seem to have had a regional impact on carbonatite complexes. The lithological control of sulfur mineralization is observed in the studied area (i.e., sulfides occur in high-Ti rocks, and sulfates are distributed in REE-Sr-Ba rocks). The transition from sulfide mineralization to sulfate mineralization presumably was caused by a change in oxidizing conditions in the fluid during the waning stages of metasomatism. As shown for the carbonatites from the Bear Lodge, the reason for this phenomenon could be an influx of external (meteoric) fluid [70,72].

The mineral composition of carbonatites at Petyayan-Vara does not reflect the influence of chlorine. However, barium is poorly transported by sulfur-rich fluid due to precipitation of baryte by the reaction of $\mathrm{Ba}^{2+}$ with sulfate [147]. In the empirical modelling study of [147], baryte solubility was conditioned 
by $\mathrm{Cl}$ content (the main factor) in the fluid, as well as temperature and pressure. Thus, the fluid most likely contained both sulfur and chlorine.

The similar mineral composition of burbankite pseudomorphs and ancylite assemblage indicates their formation during a single event. We suggest that $\mathrm{S}(+\mathrm{Cl}$ ?)-rich fluid caused decomposition of burbankite from primary magmatic carbonatites, thereby accumulating Sr, Ba, and REE, and then re-deposited these elements into cracks and crushing zones. This explains the specific appearance of ancylite-dominant rocks (see Figure 11a-c). As showed Andersen et al. [72], fluids responsible for the burbankite-to-ancylite conversion are predominantly magmatic (carbohydrothermal).

The formation of the baryte mineral assemblage instead of the ancylite assemblage is explained by the mechanism proposed in [36]. Initially, fluids had a high capacity to transport REE, and, consequently, no REE minerals were deposited. Cooling caused the crystallization of a large amount of baryte [147], which captured the bulk of the $S$ from the fluid. As a result, the capacity of the latter to transport REE decreased, triggering ancylite precipitation in the waning stage of (carbo)-hydrothermal activity. Evidence of a decrease in sulfur content in the fluid is the absence of celestine in the ancylite assemblage. Additionally, both the drop in pressure when the fluid infiltrated the fractured and brecciated zones and the $\mathrm{pH}$ increase under fluid-rock interactions could contribute to the deposition of ancylite [136].

The origin of coarse-grained calcite carbonatites, which are associated with ancylite ores, is enigmatic. They may have been derived from the Ba-Sr-REE fluid phase depleted in REE, $\mathrm{Sr}$, and Ba due to the precipitation of strontianite, ancylite, and baryte. Alternatively, these rocks could have originated from calciocarbonate melt residua injected after the cessation of the ancylite crystallization. The first scenario is supported by the high $a \mathrm{Ca}^{2+}$ during Ba-Sr-REE mineralization, in which dolomite is replaced by calcite near ancylite-rich areas. Syntaxial intergrowths of bastnäsite and synchysite also indicate an increase in $a \mathrm{Ca}^{2+}[80,148]$. However, the juxtaposition of Ba-Sr-REE carbonatites and late calciocarbonatites may be incidental. In this case, the latter are products of barren Ca-rich fluid circulated during the final stage of the Vuoriyarvi complex's formation.

\subsection{Late-Stage Processes}

Late-stage processes yielded breccias of magnesiocarbonatite with a matrix of quartz-bastnäsite, monazite, Fe hydroxides, quartz, and late dolomite and calcite generations. Of particular interest are the breccias of magnesiocarbonatite with a quartz-bastnäsite matrix. In addition to alkaline-ultrabasic carbonatite complexes, similar rocks, dominated by quartz and REE-fluorocarbonates occur in other types of alkaline massifs (for example, in the Jbel Boho alkaline complex, Morocco [148]; Fazenda Varela carbonatites of the Lages alkaline complex, Brazil [149]). The origin of such rocks is attributed to the remobilization of rare-earth elements from alkaline rocks by the late-stage fluids [148]. At the Palabora complex, it was shown that thorium can be used as an indicator of remobilization [65]. In the Palabora carbonatites, Th is abundant in early minerals crystallized during the main stage of REE mineralization. During remobilization, Th was incorporated into the secondary phases. In the Petyayan-Vara carbonatites, the early Th-bearing phase is apatite of the second generation crystallized during the early stage of the Ba-Sr-REE metasomatism. In minerals of the main Ba-Sr-REE deposition stage, Th content is below the detection limit. Bastnäsite contains up to several percent of Th. Apparently, the quartz-bastnäsite matrix in the dolomite carbonatite breccias also formed as a result of remobilizing the REE from preexisting minerals (primarily ancylite).

As shown above, ancylite is often pseudomorphically replaced by bastnäsite (Figures 12b, 14d and 15f). Similar pseudomorphs associated with late hydrothermal processes were found in the Bear Lodge carbonatites [68,71]. We detected the replacement of ancylite by bastnäsite exclusively in quartz-bearing carbonatites of Petyayan-Vara. This mineral replacement was obviously associated with an increase in silica activity. A likely source of silica is the host silicate rock.

In Bear Lodge carbonatites, it was shown that strontium is lost during the replacement of ancylite by bastnäsite [71]. A similar process could explain the strontianite assemblage in Ba-Sr-REE 
carbonatites and the bulk of strontianite in hybrid rocks (see Section 4.1.6). In other complexes, strontianite-dominant rocks are rather rare (e.g., $[19,150])$. From our observations of the paragenetic relationships, strontainite-dominant rocks are some of the latest rocks to form (e.g., Figure 7 in [150]).

Ancylite was not abundant in magnesiocarbonatite which was protolithic to breccias with a quartz-bastnäsite matrix. The unique matrix mineralogy is a result of remobilized REEs introduced with the silica-rich fluid. The absence of sulfur in the breccias indicates the negligible role of $S$ in REE mobility during the later hydrothermal stages. A specific feature of the Petyayan-Vara carbonatites is the predominance of hydroxylbastnäsite. The listed characteristics point to low fluorine activity and high $(\mathrm{OH})^{-}$activity in the fluid. These conditions favor thorium transfer [151]. As shown in the inclusion study of quartz-synchysite rocks in the Jbel Boho alkaline complex, the most probable REE transport ligand in such fluids is $\mathrm{Cl}$ [148].

Near early-crystallized apatite (Ap-1) and in apatite-free rocks, monazite is poor in Th but rich in $\mathrm{Ba}$ and S. Monazite in proximity to Ap-2 has higher thorium content. This substitution and the spatial association of apatite and monazite indicate the growth of the latter at the expense of apatite. A similar mechanism of monazite formation was described for the late-stage carbonatites of the Cummins Range Carbonatite Complex, Australia [7], the Fen complex, Norway [58], the Sokli complex, Finland [152], the Palabora complex, South Africa [65], and others worldwide. Presumably, thorite or huttonite (complementary to monazite) is the product of the selective concentration of elements (Th and HREE) released during apatite decomposition. A similar selective redistribution of LREE and Th-HREE has been described in carbonatites of Nolans Bore (Australia) [8].

Collomorphic monazite (see Figure 10d) was formed by the decomposition of apatite during a late hydrothermal stage. In addition to collomorphic textures, needle and fibrous monazite forms, characteristic of supergene REE mineralization (e.g., [71,153]), are present (e.g., Figure 12c). The grain morphologies of Fe oxides/hydroxides are analogous to those of monazite (collomorphic, needle, and fibrous). Some of the Fe oxides and hydroxides were likely formed by the classical decomposition scheme of Fe-containing carbonates $[88,154]$ and trapped as inclusions within newly formed carbonates. However, a substantial amount of Fe migrated during late hydrothermal and, possibly, supergene stages. In our study area, ferruginization accompanied all late-stage processes.

\section{Conclusions and Further Perspectives}

The main conclusions of this study are as follows:

1. The primary rocks of the Petyayan-Vara field were magmatic magnesiocarbonatites, consisting of dolomite with burbankite, minor magnetite, and possibly sulfides. These rocks were the protolith of all other carbonatites;

2. Mineralogical and geochemical features, including high REE contents that are characteristic of the rocks of the Petyayan-Vara field, are the result of several metasomatic events;

3. The introduction of a carbonatitic fluid (or fluid-saturated melt) rich in $\mathrm{K}, \mathrm{Al}, \mathrm{Si}, \mathrm{Fe}$, and $\mathrm{Ti}$ has resulted in the formation of high-Ti carbonatites containing $\mathrm{Nb}$-rich Ti-oxides. Local apatitization is superimposed on high-Ti carbonatites and the surrounding rocks;

4. The most pervasive alteration of magnesiocarbonatites was caused by a magmatic $\mathrm{S}(+\mathrm{Cl}$ ?)-rich fluid with high concentrations of $\mathrm{Ba}, \mathrm{Sr}$, and REE. At this stage, baryte-strontianite-ancylite ores with high REE contents (up to $11 \mathrm{wt}$. \% total REE) were formed;

5. Initially, Ba-Sr-REE-S fluid had a high capacity to transport REE, and, consequently, no REE minerals were deposited. Cooling caused the crystallization of a large amount of baryte, which captured the bulk of the $S$ from the fluid. As a result, the capacity of the latter to transport REE decreased, triggering ancylite precipitation in the waning stage of (carbo)- hydrothermal activity. This mechanism explains the formation of the baryte mineral assemblage instead of the ancylite assemblage; 
6. Interaction with the Ba-Sr-REE-S fluid caused replacement of early-formed apatite with a secondary HREE-rich generation of apatite;

7. Late-stage processes yielded breccias of magnesiocarbonatites with a quartz-bastnäsite matrix, minerals of the strontianite assemblage, monazite, Fe hydroxides, quartz, as well as late dolomite and calcite generations.

The similarity of the mineralogical and geochemical features of the Petyayan-Vara carbonatites and late carbonatites of various complexes worldwide suggests common mechanisms of formation. A number of issues are yet to be clarified:

- The universality of the proposed HREE-enrichment mechanisms for late carbonatites;

- Ancylite stability field limits;

- $\quad$ The mechanism(s) of joint fluid migration of REE and Ba.

A clear correspondence between the results of petrographic and statistical studies points out the high efficiency of the described statistical approaches for the study of such complex geological objects as late carbonatites.

Supplementary Materials: The following are available online at http://www.mdpi.com/2075-163X/10/1/73/s1, Table S1: The measured contents of major and trace elements. Table S2: Representative analyses of the minerals.

Author Contributions: E.K. conceived and designed the experiments; E.K., E.F., M.S. and A.C. conducted field research; E.K., E.F. and M.S. studied petrography and mineralogy of rocks; V.S., V.B. and M.H. conducted mineralogical analyses; E.K. and A.C. designed figures and tables. The manuscript was written by E.K. and E.F., with contributions from V.S. All authors have read and agreed to the published version of the manuscript.

Funding: This research was funded by the Russian Science Foundation, grant number 19-77-10039. Field work was supported by the Geological Institute KSC RAS, state order number 0226-2019-0053.

Acknowledgments: The authors express their sincere appreciation to N.A. Priyatkina (IES SPbSU) for help with translation. All samples were collected and first processed by the authors with the help of S.V. Petrov (IES SPbSU) and O.V. Kasanov (VIMS). We kindly thank V.N. Bocharov (RC "Geomodel" SPbSU) and A.V. Bazai (GI KSC RAS) for their assistance in studying the structure and composition of the minerals. L.I. Konstantinova (GI KSC RAS) assisted with analysis of major elements in rocks and I.R. Elizarova (ICTREMR KSC RAS) assisted with LA-ICP-MS. Thorough reviews by four anonymous reviewers significantly improved the manuscript.

Conflicts of Interest: The authors declare no conflict of interest.

\section{References}

1. Chakhmouradian, A.R.; Wall, F. Rare Earth Elements: Minerals, Mines, Magnets (and More). Elements 2012, 8, 333-340. [CrossRef]

2. Wall, F. Rare earth elements. In Critical Metals Handbook; John Wiley \& Sons: Oxford, UK, 2013; pp. 312-339. ISBN 9781118755341.

3. Le Maitre, R.W.; Streckeisen, A.; Zanettin, B.; Le Bas, M.J.; Bonin, B.; Bateman, P.; Bellieni, G.; Dudek, A.; Efremova, S.; Keller, J.; et al. Igneous Rocks: A Classification and Glossary of Terms. Recommendations of the International Union of Geological Sciences Subcommission on the Systematics of Igneous Rocks, 2nd ed.; Le Maitre, R.W., Ed.; Cambridge University Press: Cambridge, UK, 2002; ISBN 9780521619486.

4. Weng, Z.; Jowitt, S.M.; Mudd, G.M.; Haque, N. A Detailed Assessment of Global Rare Earth Element Resources: Opportunities and Challenges. Econ. Geol. 2015, 110, 1925-1952. [CrossRef]

5. Amores-Casals, S.; Gonçalves, A.O.; Melgarejo, J.-C.; Martí Molist, J. Nb and REE Distribution in the Monte Verde Carbonatite-Alkaline-Agpaitic Complex (Angola). Minerals 2019, 10, 5. [CrossRef]

6. Casals, A.-C.; Melgarejo, J.-C.; Bambi, A.; Gonçalves, A.O.; Morais, E.A.; Manuel, J.; Neto, A.B.; Costanzo, A.; Molist, J.M.; Amores-Casals, S.; et al. Lamprophyre-Carbonatite Magma Mingling and Subsolidus Processes as Key Controls on Critical Element Concentration in Carbonatites-The Bonga Complex (Angola). Minerals 2019, 9, 601. [CrossRef] 
7. Downes, P.J.; Demény, A.; Czuppon, G.; Jaques, A.L.; Verrall, M.; Sweetapple, M.; Adams, D.; McNaughton, N.J.; Gwalani, L.G.; Griffin, B.J. Stable H-C-O isotope and trace element geochemistry of the Cummins Range Carbonatite Complex, Kimberley region, Western Australia: Implications for hydrothermal REE mineralization, carbonatite evolution and mantle source regions. Min. Depos. 2014, 49, 905-932. [CrossRef]

8. Anenburg, M.; Burnham, A.D.; Mavrogenes, J.A. REE Redistribution Textures in Altered Fluorapatite: Symplectites, Veins, and Phosphate-Silicate-Carbonate Assemblages from the Nolans Bore P-REE-Th Deposit, Northern Territory, Australia. Can. Miner. 2018, 56, 331-354. [CrossRef]

9. Anenburg, M.; Mavrogenes, J.A. Carbonatitic versus hydrothermal origin for fluorapatite REE-Th deposits: Experimental study of REE transport and crustal "antiskarn" metasomatism. Am. J. Sci. 2018, 318, 335-366. [CrossRef]

10. Guarino, V.; Wu, F.-Y.; Melluso, L.; de Barros Gomes, C.; Tassinari, C.C.G.; Ruberti, E.; Brilli, M. U-Pb ages, geochemistry, $\mathrm{C}-\mathrm{O}-\mathrm{Nd}-\mathrm{Sr}-\mathrm{Hf}$ isotopes and petrogenesis of the Catalão II carbonatitic complex (Alto Paranaíba Igneous Province, Brazil): Implications for regional-scale heterogeneities in the Brazilian carbonatite associations. Int. J. Earth Sci. 2017, 106, 1963-1989. [CrossRef]

11. Giovannini, A.L.; Bastos Neto, A.C.; Porto, C.G.; Pereira, V.P.; Takehara, L.; Barbanson, L.; Bastos, P.H.S. Mineralogy and geochemistry of laterites from the Morro dos Seis Lagos $\mathrm{Nb}$ (Ti, REE) deposit (Amazonas, Brazil). Ore Geol. Rev. 2017, 88, 461-480. [CrossRef]

12. Dalsin, M.L.; Groat, L.A.; Creighton, S.; Evans, R.J. The mineralogy and geochemistry of the Wicheeda Carbonatite Complex, British Columbia, Canada. Ore Geol. Rev. 2015, 64, 523-542. [CrossRef]

13. Nadeau, O.; Cayer, A.; Pelletier, M.; Stevenson, R.; Jébrak, M. The Paleoproterozoic Montviel carbonatite-hosted REE-Nb deposit, Abitibi, Canada: Geology, mineralogy, geochemistry and genesis. Ore Geol. Rev. 2015, 67, 314-335. [CrossRef]

14. Trofanenko, J.; Williams-Jones, A.E.; Simandl, G.J.; Migdisov, A.A. The Nature and Origin of the REE Mineralization in the Wicheeda Carbonatite, British Columbia, Canada. Econ. Geol. 2016, 111, 199-223. [CrossRef]

15. Mitchell, R.H.; Smith, D.L. Geology and mineralogy of the Ashram Zone carbonatite, Eldor Complex, Québec. Ore Geol. Rev. 2017, 86, 784-806. [CrossRef]

16. Néron, A.; Bédard, L.; Gaboury, D. The Saint-Honoré Carbonatite REE Zone, Québec, Canada: Combined Magmatic and Hydrothermal Processes. Minerals 2018, 8, 397. [CrossRef]

17. Pandur, K.; Ansdell, K.M.; Kontak, D.J. Graphic-textured inclusions in apatite: Evidence for pegmatitic growth in a REE-enriched carbonatitic system. Geology 2015, 43, 547-550. [CrossRef]

18. Smith, M.P.; Campbell, L.S.; Kynicky, J. A review of the genesis of the world class Bayan Obo Fe-REE-Nb deposits, Inner Mongolia, China: Multistage processes and outstanding questions. Ore Geol. Rev. 2015, 64, 459-476. [CrossRef]

19. Xie, Y.; Li, Y.; Hou, Z.; Cooke, D.R.; Danyushevsky, L.; Dominy, S.C.; Yin, S. A model for carbonatite hosted REE mineralisation-The Mianning-Dechang REE belt, Western Sichuan Province, China. Ore Geol. Rev. 2015, 70, 595-612. [CrossRef]

20. Shu, X.; Liu, Y. Fluid inclusion constraints on the hydrothermal evolution of the Dalucao Carbonatite-related REE deposit, Sichuan Province, China. Ore Geol. Rev. 2019, 107, 41-57. [CrossRef]

21. Zheng, X.; Liu, Y. Mechanisms of element precipitation in carbonatite-related rare-earth element deposits: Evidence from fluid inclusions in the Maoniuping deposit, Sichuan Province, southwestern China. Ore Geol. Rev. 2019, 107, 218-238. [CrossRef]

22. Bai, T.; Chen, W.; Jiang, S.-Y. Evolution of the carbonatite Mo-HREE deposits in the Lesser Qinling Orogen: Insights from in situ geochemical investigation of calcite and sulfate. Ore Geol. Rev. 2019, 113, 103069. [CrossRef]

23. Zhang, D.; Liu, Y.; Pan, J.; Dai, T.; Bayless, R.C. Mineralogical and geochemical characteristics of the Miaoya REE prospect, Qinling orogenic Belt, China: Insights from Sr-Nd-C-O isotopes and LA-ICP-MS mineral chemistry. Ore Geol. Rev. 2019, 110, 102932. [CrossRef]

24. Jia, Y.; Liu, Y. REE Enrichment during Magmatic-Hydrothermal Processes in Carbonatite-Related REE Deposits: A Case Study of the Weishan REE Deposit, China. Minerals 2019, 10, 25. [CrossRef] 
25. Su, J.-H.; Zhao, X.-F.; Li, X.-C.; Hu, W.; Chen, M.; Xiong, Y.-L. Geological and geochemical characteristics of the Miaoya syenite-carbonatite complex, Central China: Implications for the origin of REE-Nb-enriched carbonatite. Ore Geol. Rev. 2019, 113, 103101. [CrossRef]

26. Wang, C.; Liu, J.; Zhang, H.; Zhang, X.; Zhang, D.; Xi, Z.; Wang, Z. Geochronology and mineralogy of the Weishan carbonatite in Shandong province, eastern China. Geosci. Front. 2019, 10, 769-785. [CrossRef]

27. Song, W.; Xu, C.; Smith, M.P.; Chakhmouradian, A.R.; Brenna, M.; Kynický, J.; Chen, W.; Yang, Y.; Deng, M.; Tang, H. Genesis of the world's largest rare earth element deposit, Bayan Obo, China: Protracted mineralization evolution over $\sim 1$ b.y. Geology 2018, 46. [CrossRef]

28. Chen, W.; Lu, J.; Jiang, S.-Y.; Ying, Y.-C.; Liu, Y.-S. Radiogenic Pb reservoir contributes to the rare earth element (REE) enrichment in South Qinling carbonatites. Chem. Geol. 2018, 494, 80-95. [CrossRef]

29. Song, W.; Xu, C.; Smith, M.P.; Kynicky, J.; Huang, K.; Wei, C.; Zhou, L.; Shu, Q. Origin of unusual HREE-Mo-rich carbonatites in the Qinling orogen, China. Sci. Rep. 2016, 6, 37377. [CrossRef]

30. Fan, H.-R.; Yang, K.-F.; Hu, F.-F.; Liu, S.; Wang, K.-Y. The giant Bayan Obo REE-Nb-Fe deposit, China: Controversy and ore genesis. Geosci. Front. 2016, 7, 335-344. [CrossRef]

31. Feng, M.; Xu, C.; Kynicky, J.; Zeng, L.; Song, W. Rare earth element enrichment in Palaeoproterozoic Fengzhen carbonatite from the North China block. Int. Geol. Rev. 2016, 58, 1940-1950. [CrossRef]

32. Deng, M.; Xu, C.; Song, W.; Tang, H.; Liu, Y.; Zhang, Q.; Zhou, Y.; Feng, M.; Wei, C. REE mineralization in the Bayan Obo deposit, China: Evidence from mineral paragenesis. Ore Geol. Rev. 2017, 91, 100-109. [CrossRef]

33. Yang, X.; Lai, X.; Pirajno, F.; Liu, Y.; Mingxing, L.; Sun, W. Genesis of the Bayan Obo Fe-REE-Nb formation in Inner Mongolia, North China Craton: A perspective review. Precambrian Res. 2017, 288, 39-71. [CrossRef]

34. Smith, M.; Kynicky, J.; Xu, C.; Song, W.; Spratt, J.; Jeffries, T.; Brtnicky, M.; Kopriva, A.; Cangelosi, D. The origin of secondary heavy rare earth element enrichment in carbonatites: Constraints from the evolution of the Huanglongpu district, China. Lithos 2018, 308-309, 65-82. [CrossRef]

35. Cheng, Z.; Zhang, Z.; Aibai, A.; Kong, W.; Holtz, F. The role of magmatic and post-magmatic hydrothermal processes on rare-earth element mineralization: A study of the Bachu carbonatites from the Tarim Large Igneous Province, NW China. Lithos 2018, 314-315, 71-87. [CrossRef]

36. Liu, Y.; Chakhmouradian, A.R.; Hou, Z.; Song, W.; Kynický, J. Development of REE mineralization in the giant Maoniuping deposit (Sichuan, China): Insights from mineralogy, fluid inclusions, and trace-element geochemistry. Min. Depos. 2018. [CrossRef]

37. Guo, D.; Liu, Y. Occurrence and geochemistry of bastnäsite in carbonatite-related REE deposits, Mianning-Dechang REE belt, Sichuan Province, SW China. Ore Geol. Rev. 2019, 107, 266-282. [CrossRef]

38. Al-Ani, T.; Molnár, F.; Lintinen, P.; Leinonen, S.; Al-Ani, T.; Molnár, F.; Lintinen, P.; Leinonen, S. Geology and Mineralogy of Rare Earth Elements Deposits and Occurrences in Finland. Minerals 2018, 8, 356. [CrossRef]

39. Bhushan, S.K. Geology of the Kamthai Rare Earth Deposit. J. Geol. Soc. India 2015, 85, 537-546. [CrossRef]

40. Krishnamurthy, P. Carbonatites of India. J. Geol. Soc. India 2019, 94, 117-138. [CrossRef]

41. Nagabhushanam, B.; Durai Raju, S.; Mundra, K.L.; Rai, S.D.; Purohit, R.K.; Verma, M.B.; Nanda, L.K. LREE-Nb Mineralization in the South Western Part of Ambadongar Carbonatite Complex, Chhota Udepur District, Gujarat, India. Curr. Sci. 2018, 114, 1608. [CrossRef]

42. Viladkar, S.G. Ferrocarbonatites in the Amba Dongar Diatreme, Gujarat, India. J. Geol. Soc. India 2018, 92, 141-144. [CrossRef]

43. Stoppa, F.; Pirajno, F.; Schiazza, M.; Vladykin, N.V. State of the art: Italian carbonatites and their potential for critical-metal deposits. Gondwana Res. 2016, 37, 152-171. [CrossRef]

44. Stoppa, F.; Schiazza, M.; Rosatelli, G.; Castorina, F.; Sharygin, V.V.; Ambrosio, F.A.; Vicentini, N. Italian carbonatite system: From mantle to ore-deposit. Ore Geol. Rev. 2019, 114. [CrossRef]

45. Duraiswami, R.; Shaikh, T. Fluid-rock interaction in the Kangankunde Carbonatite Complex, Malawi: SEM based evidence for late stage pervasive hydrothermal mineralisation. Open Geosci. 2014, 6. [CrossRef]

46. Broom-Fendley, S.; Heaton, T.; Wall, F.; Gunn, G. Tracing the fluid source of heavy REE mineralisation in carbonatites using a novel method of oxygen-isotope analysis in apatite: The example of Songwe Hill, Malawi. Chem. Geol. 2016, 440, 275-287. [CrossRef]

47. Broom-Fendley, S.; Brady, A.E.; Horstwood, M.S.A.; Woolley, A.R.; Mtegha, J.; Wall, F.; Dawes, W.; Gunn, G. Geology, geochemistry and geochronology of the Songwe Hill carbonatite, Malawi. J. Afr. Earth Sci. 2017, 134, 10-23. [CrossRef] 
48. Broom-Fendley, S.; Brady, A.E.; Wall, F.; Gunn, G.; Dawes, W. REE minerals at the Songwe Hill carbonatite, Malawi: HREE-enrichment in late-stage apatite. Ore Geol. Rev. 2017, 81, 23-41. [CrossRef]

49. Broom-Fendley, S.; Wall, F.; Spiro, B.; Ullmann, C.V. Deducing the source and composition of rare earth mineralising fluids in carbonatites: Insights from isotopic (C, O, 87Sr/86Sr) data from Kangankunde, Malawi. Contrib. Mineral. Petrol. 2017, 172, 96. [CrossRef]

50. Dowman, E.; Wall, F.; Treloar, P.J.J.; Rankin, A.H.H. Rare-earth mobility as a result of multiple phases of fluid activity in fenite around the Chilwa Island Carbonatite, Malawi. Mineral. Mag. 2017, 81, 1367-1395. [CrossRef]

51. Chikanda, F.; Otake, T.; Ohtomo, Y.; Ito, A.; Yokoyama, T.D.; Sato, T. Magmatic-Hydrothermal Processes Associated with Rare Earth Element Enrichment in the Kangankunde Carbonatite Complex, Malawi. Minerals 2019, 9, 442. [CrossRef]

52. Kynicky, J.; Smith, M.P.; Song, W.; Chakhmouradian, A.R.; Xu, C.; Kopriva, A.; Galiova, M.V.; Brtnicky, M. The role of carbonate-fluoride melt immiscibility in shallow REE deposit evolution. Geosci. Front. 2018. [CrossRef]

53. Feng, M.; Song, W.; Kynicky, J.; Smith, M.; Cox, C.; Kotlanova, M.; Brtnicky, M.; Fu, W.; Wei, C. Primary rare earth element enrichment in carbonatites: Evidence from melt inclusions in Ulgii Khiid carbonatite, Mongolia. Ore Geol. Rev. 2019, 1675, 103294. [CrossRef]

54. Bodeving, S.; Williams-Jones, A.E.; Swinden, S. Carbonate-silicate melt immiscibility, REE mineralising fluids, and the evolution of the Lofdal Intrusive Suite, Namibia. Lithos 2017, 268-271, 383-398. [CrossRef]

55. Broom-Fendley, S.; Smith, M.; Andrade, M.B.; Ray, S.; Banks, D.A.; Loye, E.; Atencio, D.; Pickles, J.R.; Wall, F. Sulfur-bearing monazite-(Ce) from the Eureka carbonatite, Namibia: Oxidation state, substitution mechanism, and formation conditions. Mineral. Mag. 2019, 1-44. [CrossRef]

56. Cangelosi, D.; Broom-Fendley, S.; Banks, D.; Morgan, D.; Yardley, B. Light rare earth element redistribution during hydrothermal alteration at the Okorusu carbonatite complex, Namibia. Mineral. Mag. 2019, 1-16. [CrossRef]

57. Cooper, A.F.; Collins, A.K.; Palin, J.M.; Spratt, J. Mineralogical evolution and REE mobility during crystallisation of ancylite-bearing ferrocarbonatite, Haast River, New Zealand. Lithos 2015, 216-217, 324-337. [CrossRef]

58. Marien, C.; Dijkstra, A.H.; Wilkins, C. The hydrothermal alteration of carbonatite in the Fen Complex, Norway: Mineralogy, geochemistry, and implications for rare-earth element resource formation. Mineral. Mag. 2018, 82, S115-S131. [CrossRef]

59. Zaitsev, A.N.; Terry Williams, C.; Jeffries, T.E.; Strekopytov, S.; Moutte, J.; Ivashchenkova, O.V.; Spratt, J.; Petrov, S.V.; Wall, F.; Seltmann, R.; et al. 'Rare earth elements in phoscorites and carbonatites of the Devonian Kola Alkaline Province, Russia: Examples from Kovdor, Khibina, Vuoriyarvi and Turiy Mys complexes'. Ore Geol. Rev. 2015, 64, 477-498. [CrossRef]

60. Lazareva, E.V.; Zhmodik, S.M.; Dobretsov, N.L.; Tolstov, A.V.; Shcherbov, B.L.; Karmanov, N.S.; Gerasimov, E.Y.; Bryanskaya, A.V. Main minerals of abnormally high-grade ores of the Tomtor deposit (Arctic Siberia). Russ. Geol. Geophys. 2015, 56, 844-873. [CrossRef]

61. Doroshkevich, A.G.; Veksler, I.V.; Izbrodin, I.A.; Ripp, G.S.; Khromova, E.A.; Posokhov, V.F.; Travin, A.V.; Vladykin, N.V. Stable isotope composition of minerals in the Belaya Zima plutonic complex, Russia: Implications for the sources of the parental magma and metasomatizing fluids. J. Asian Earth Sci. 2016, 116, 81-96. [CrossRef]

62. Prokopyev, I.R.; Borisenko, A.S.; Borovikov, A.A.; Pavlova, G.G. Origin of REE-rich ferrocarbonatites in southern Siberia (Russia): Implications based on melt and fluid inclusions. Mineral. Petrol. 2016, 110, 845-859. [CrossRef]

63. Doroshkevich, A.G.; Chebotarev, D.A.; Sharygin, V.V.; Prokopyev, I.R.; Nikolenko, A.M. Petrology of alkaline silicate rocks and carbonatites of the Chuktukon massif, Chadobets upland, Russia: Sources, evolution and relation to the Triassic Siberian LIP. Lithos 2019, 332-333, 245-260. [CrossRef]

64. Prokopyev, I.R.; Doroshkevich, A.G.; Redina, A.A.; Obukhov, A.V. Magnetite-apatite-dolomitic rocks of Ust-Chulman (Aldan shield, Russia): Seligdar-type carbonatites? Mineral. Petrol. 2018, 112, 257-266. [CrossRef]

65. Giebel, R.J.; Gauert, C.D.K.; Marks, M.A.W.; Costin, G.; Markl, G. Multi-stage formation of REE minerals in the Palabora Carbonatite Complex, South Africa. Am. Mineral. 2017, 102, 1218-1233. [CrossRef] 
66. Milani, L.; Bolhar, R.; Frei, D.; Harlov, D.E.; Samuel, V.O. Light rare earth element systematics as a tool for investigating the petrogenesis of phoscorite-carbonatite associations, as exemplified by the Phalaborwa Complex, South Africa. Miner. Depos. 2017, 52, 1105-1125. [CrossRef]

67. Witt, W.K.; Hammond, D.P.; Hughes, M. Geology of the Ngualla carbonatite complex, Tanzania, and origin of the Weathered Bastnaesite Zone REE ore. Ore Geol. Rev. 2019, 105, 28-54. [CrossRef]

68. Moore, M.; Chakhmouradian, A.R.; Mariano, A.N.; Sidhu, R. Evolution of rare-earth mineralization in the Bear Lodge carbonatite, Wyoming: Mineralogical and isotopic evidence. Ore Geol. Rev. 2015, 64, 499-521. [CrossRef]

69. Andersen, A.K.; Clark, J.G.; Larson, P.B.; Neill, O.K. Mineral chemistry and petrogenesis of a HFSE(+HREE) occurrence, peripheral to carbonatites of the Bear Lodge alkaline complex, Wyoming. Am. Mineral. 2016, 101, 1604-1623. [CrossRef]

70. Chakhmouradian, A.R.; Cooper, M.A.; Reguir, E.P.; Moore, M.A. Carbocernaite from Bear Lodge, Wyoming: Crystal chemistry, paragenesis, and rare-earth fractionation on a microscale. Am. Mineral. 2017, 102, 1340-1352. [CrossRef]

71. Andersen, A.K.; Clark, J.G.; Larson, P.B.; Donovan, J.J. REE fractionation, mineral speciation, and supergene enrichment of the Bear Lodge carbonatites, Wyoming, USA. Ore Geol. Rev. 2017, 89, 780-807. [CrossRef]

72. Andersen, A.K.; Larson, P.B.; Cosca, M.A. C-O stable isotope geochemistry and 40Ar/39Ar geochronology of the Bear Lodge carbonatite stockwork, Wyoming, USA. Lithos 2019, 324-325, 640-660. [CrossRef]

73. Nguyen Thi, T.; Wada, H.; Ishikawa, T.; Shimano, T. Geochemistry and petrogenesis of carbonatites from South Nam Xe, Lai Chau area, northwest Vietnam. Mineral. Petrol. 2014, 108, 371-390. [CrossRef]

74. Harmer, R.E.; Nex, P.A.M. Rare Earth Deposits of Africa. Episodes 2016, 39, 381. [CrossRef]

75. Goodenough, K.M.; Schilling, J.; Jonsson, E.; Kalvig, P.; Charles, N.; Tuduri, J.; Deady, E.A.; Sadeghi, M.; Schiellerup, H.; Müller, A.; et al. Europe's rare earth element resource potential: An overview of REE metallogenetic provinces and their geodynamic setting. Ore Geol. Rev. 2016, 72, 838-856. [CrossRef]

76. Simandl, G.J.; Paradis, S. Carbonatites: Related ore deposits, resources, footprint, and exploration methods. Appl. Earth Sci. Trans. Inst. Min. Metall. 2018, 127, 123-152. [CrossRef]

77. Goodenough, K.M.; Wall, F.; Merriman, D. The Rare Earth Elements: Demand, Global Resources, and Challenges for Resourcing Future Generations. Nat. Resour. Res. 2018, 27, 201-216. [CrossRef]

78. Zaitsev, A.N.; Wall, F.; Bas, M.J. Le REE-Sr-Ba minerals from the Khibina carbonatites, Kola Peninsula, Russia: Their mineralogy, paragenesis and evolution. Mineral. Mag. 1998, 62, 225-250. [CrossRef]

79. Doroshkevich, A.G.; Ripp, G.S.; Moore, K.R. Genesis of the Khaluta alkaline-basic Ba-Sr carbonatite complex (West Transbaikala, Russia). Mineral. Petrol. 2010, 98, 245-268. [CrossRef]

80. Ngwenya, B.T. Hydrothermal rare earth mineralisation in carbonatites of the Tundulu complex, Malawi: Processes at the fluid/rock interface. Geochim. Cosmochim. Acta 1994, 58, 2061-2072. [CrossRef]

81. Broom-Fendley, S.; Styles, M.T.; Appleton, J.D.; Gunn, G.; Wall, F. Evidence for dissolution-reprecipitation of apatite and preferential LREE mobility in carbonatite-derived late-stage hydrothermal processes. Am. Mineral. 2016, 101, 596-611. [CrossRef]

82. Nadeau, O.; Stevenson, R.; Jébrak, M. Evolution of Montviel alkaline-carbonatite complex by coupled fractional crystallization, fluid mixing and metasomatism-part I: Petrography and geochemistry of metasomatic aegirine-augite and biotite: Implications for REE-Nb mineralization. Ore Geol. Rev. 2016, 72, 1143-1162. [CrossRef]

83. Afanasyev, B.V. Mineral Resources of the Alkaline-Ultramafic Massifs of the Kola Peninsula; Roza Vetrov: St. Petersburg, Russia, 2011. (In Russian)

84. Downes, H.; Balaganskaya, E.; Beard, A.; Liferovich, R.; Demaiffe, D. Petrogenetic processes in the ultramafic, alkaline and carbonatitic magmatism in the Kola Alkaline Province: A review. Lithos 2005, 85, 48-75. [CrossRef]

85. Chakhmouradian, A.R.; Reguir, E.P.; Kressall, R.D.; Crozier, J.; Pisiak, L.K.; Sidhu, R.; Yang, P. Carbonatite-hosted niobium deposit at Aley, northern British Columbia (Canada): Mineralogy, geochemistry and petrogenesis. Ore Geol. Rev. 2015, 64, 642-666. [CrossRef]

86. Woolley, A.R.; Kempe, D.R.C. Carbonatites: Nomenclature, average chemical compositions, and element distribution. In Carbonatites: Genesis and Evolution; Bell, K., Ed.; Unwin Hyman: London, UK, 1989; pp. 1-14. 
87. Kravchenko-Berezhnoy, R.A.; Medvedeva, E.M.; Pakhomovsky, Y.A.; Polezhaeva, L.I.; Rezhenova, S.A. Combined usage of microprobe MS-46 and computer 'Nairi-2'. In Instrumental Methods of Mineral Studies and Usage of Electronic Computing Devices; Kravchenko-Berezhnoy, R.A., Ed.; Kola Branch USSR Academy of Sciences: Apatity, Russia, 1976; pp. 46-69. (In Russian)

88. Andersen, T. Secondary processes in carbonatites: Petrology of "rødberg" (hematite-calcite-dolomite carbonatite) in the Fen central complex, Telemark (South Norway). Lithos 1984, 17, 227-245. [CrossRef]

89. Atencio, D.; Gieré, R.; Andrade, M.B.; Christy, A.G.; Kartashov, P.M. The pyrochlore supergroup of minerals: Nomenclature. Can. Mineral. 2010, 48, 673-678. [CrossRef]

90. Kozlov, E.; Fomina, E.; Sidorov, M.; Shilovskikh, V. Ti-Nb Mineralization of Late Carbonatites and Role of Fluids in Its Formation: Petyayan-Vara Rare-Earth Carbonatites (Vuoriyarvi Massif, Russia). Geosciences 2018, 8, 281. [CrossRef]

91. Flohr, M.J.K. Titanium, vanadium, and niobium mineralization and alkali metasomatism from the Magnet Cove Complex, Arkansas. Econ. Geol. 1994, 89, 105-130. [CrossRef]

92. Werner, M.; Cook, N.J. Nb-rich brookite from Gross Brukkaros, Namibia: Substitution mechanisms and Fe2+/Fe3+ ratios. Mineral. Mag. 2001, 65, 437-440. [CrossRef]

93. Verwoerd, W.J.; Viljoen, E.A.; Chevallier, L. Rare metal mineralization at the Salpeterkop carbonatite complex, Western Cape Province, South Africa. J. Afr. Earth Sci. 1995, 21, 171-186. [CrossRef]

94. Bulakh, A.G.; Nesterov, A.R.; Zaitsev, A.N.; Pilipiuk, A.N.; Wall, F.; Kirillov, A.S. Sulfur-containing monazite-(Ce) from late-stage mineral assemblages at the Kandaguba and Vuoriyarvi carbonatite complexes, Kola peninsula, Russia. Neues Jahrb. Fur Mineral. Mon. 2000, 5, 217-233.

95. Torró, L.; Villanova, C.; Castillo, M.; Campeny, M.; Gonçalves, A.O.; Melgarejo, J.C. Niobium and rare earth minerals from the Virulundo carbonatite, Namibe, Angola. Mineral. Mag. 2012, 76, 393-409. [CrossRef]

96. Savelyeva, V.B.; Bazarova, E.P.; Sharygin, V.V.; Karmanov, N.S.; Kanakin, S.V. Altered rocks of the Onguren carbonatite complex in the Western Tansbaikal Region: Geochemistry and composition of accessory minerals. Geol. Ore Depos. 2017, 59, 315-340. [CrossRef]

97. Wall, F.; Zaitsev, A.; Jones, A.P.; Mariano, A.N. Rare-earth rich carbonatites: A review and latest results. J. Czech Geol. Soc. 1997, 42, 49.

98. Silva, E.N.; Ayala, A.P.; Guedes, I.; Paschoal, C.W.A.; Moreira, R.L.; Loong, C.-K.; Boatner, L.A. Vibrational spectra of monazite-type rare-earth orthophosphates. Opt. Mater. 2006, 29, 224-230. [CrossRef]

99. Clavier, N.; Mesbah, A.; Szenknect, S.; Dacheux, N. Monazite, rhabdophane, xenotime \& churchite: Vibrational spectroscopy of gadolinium phosphate polymorphs. Spectrochim. Acta Part A Mol. Biomol. Spectrosc. 2018, 205, 85-94. [CrossRef]

100. Heuser, J.; Bukaemskiy, A.A.; Neumeier, S.; Neumann, A.; Bosbach, D. Raman and infrared spectroscopy of monazite-type ceramics used for nuclear waste conditioning. Prog. Nucl. Energy 2014, 72, 149-155. [CrossRef]

101. Assaaoudi, H.; Ennaciri, A.; Rulmont, A. Vibrational spectra of hydrated rare earth orthophosphates. Vib. Spectrosc. 2001, 25, 81-90. [CrossRef]

102. Valenzano, L.; Noël, Y.; Orlando, R.; Zicovich-Wilson, C.M.; Ferrero, M.; Dovesi, R. Ab initio vibrational spectra and dielectric properties of carbonates: Magnesite, calcite and dolomite. Theor. Chem. Acc. 2007, 117, 991-1000. [CrossRef]

103. Gunasekaran, S.; Anbalagan, G.; Pandi, S. Raman and infrared spectra of carbonates of calcite structure. J. Raman Spectrosc. 2006, 37, 892-899. [CrossRef]

104. Yang, H.; Dembowski, R.F.; Conrad, P.G.; Downs, R.T. Crystal structure and Raman spectrum of hydroxyl-bastnasite-(Ce), CeCO3(OH). Am. Mineral. 2008, 93, 698-701. [CrossRef]

105. Frost, R.L.; Dickfos, M.J. Raman spectroscopy of halogen-containing carbonates. J. Raman Spectrosc. 2007, 38, 1516-1522. [CrossRef]

106. Kirillov, A.S. Hydroxyl bastnäsite, a new variety of basnäsite. Dokl. Akad. Nauk SssrEarth Sci. Sect. 1964, 159, 93-95.

107. Lafuente, B.; Downs, R.T.; Yang, H.; Stone, N. The power of databases: The RRUFF project. In Highlights in Mineralogical Crystallography; Armbruster, T., Danisi, R.M., Eds.; DE GRUYTER: Berlin, Germany, 2015; pp. 1-30. 
108. Ruberti, E.; Enrich, G.E.R.; Gomes, C.B.; Comin-Chiaramonti, P. Hydrothermal REE fluorocarbonate mineralization at Barra do Itapirapuã, a multiple stockwork carbonatite, southern Brazil. Can. Mineral. 2008, 46, 901-914. [CrossRef]

109. Andrade, F.R.D.; Möller, P.; Lüders, V.; Dulski, P.; Gilg, H.A. Hydrothermal rare earth elements mineralization in the Barra do Itapirapuã carbonatite, southern Brazil: Behavior of selected trace elements and stable isotopes (C,O). Chem. Geol. 1999, 155, 91-113. [CrossRef]

110. Sitnikova, M.A.; Zaitsev, A.N.; Wall, F.; Chakhmouradian, A.R.; Subbotin, V.V. Evolution of chemical composition of rock-forming carbonates in Sallanlatvi carbonatites, Kola Peninsula, Russia. J. Afr. Earth Sci. 2001, 32, A34. [CrossRef]

111. Doroshkevich, A.G.; Viladkar, S.G.; Ripp, G.S.; Burtseva, M.V. Hydrothermal REE mineralization in the Amba Dongar carbonatite complex, Gujarat, India. Can. Mineral. 2009, 47, 1105-1116. [CrossRef]

112. Castor, S.B. The Mountain Pass rare-earth carbonatite and associated ultrapotassic rocks, California. Can. Mineral. 2008, 46, 779-806. [CrossRef]

113. Liu, Y.; Hou, Z. A synthesis of mineralization styles with an integrated genetic model of carbonatite-syenite-hosted REE deposits in the Cenozoic Mianning-Dechang REE metallogenic belt, the eastern Tibetan Plateau, southwestern China. J. Asian Earth Sci. 2017, 137, 35-79. [CrossRef]

114. McDonough, W.F.; Sun, S.-S. The composition of the Earth. Chem. Geol. 1995, 120, 223-253. [CrossRef]

115. Chakhmouradian, A.R.; Reguir, E.P.; Couëslan, C.; Yang, P. Calcite and dolomite in intrusive carbonatites. II. Trace-element variations. Mineral. Petrol. 2016, 110, 361-377. [CrossRef]

116. Jöreskog, K.G.; Klovan, J.E.; Reyment, R.A. Geological Factor Analysis; Elsevier Scientific Pub. Co: Amsterdam, The Netherlands, 1976; ISBN 0-444-41367-7.

117. Le Maitre, R.W. Numerical Petrology: Ststistical Interpretation of Geochemical Data; Elsevier Scientific Pub. Co: Amsterdam, The Netherlands, 1982; ISBN 9780444420985.

118. Fomina, E.; Kozlov, E.; Ivashevskaja, S. Study of diffraction data sets using factor analysis: A new technique for comparing mineralogical and geochemical data and rapid diagnostics of the mineral composition of large collections of rock samples. Powder Diffr. 2019, 34, 1-12. [CrossRef]

119. Jones, A.P.; Genge, M.; Carmody, L. Carbonate Melts and Carbonatites. Rev. Mineral. Geochem. 2013, 75, 289-322. [CrossRef]

120. Chakhmouradian, A.R.; Reguir, E.P.; Zaitsev, A.N. Calcite and dolomite in intrusive carbonatites. I. Textural variations. Mineral. Petrol. 2016, 110, 333-360. [CrossRef]

121. Zaitsev, A.N.; Demény, A.; Sindern, S.; Wall, F. Burbankite group minerals and their alteration in rare earth carbonatites-source of elements and fluids (evidence from C-O and Sr-Nd isotopic data). Lithos 2002, 62, 15-33. [CrossRef]

122. Guzmics, T.; Mitchell, R.H.; Szabó, C.; Berkesi, M.; Milke, R.; Ratter, K. Liquid immiscibility between silicate, carbonate and sulfide melts in melt inclusions hosted in co-precipitated minerals from Kerimasi volcano (Tanzania): Evolution of carbonated nephelinitic magma. Contrib. Mineral. Petrol. 2012, 164, 101-122. [CrossRef]

123. Martin, L.H.J.; Schmidt, M.W.; Mattsson, H.B.; Guenther, D. Element Partitioning between Immiscible Carbonatite and Silicate Melts for Dry and H2O-bearing Systems at 1-3 GPa. J. Petrol. 2013, 54, 2301-2338. [CrossRef]

124. Jones, J.H.; Walker, D.; Pickett, D.A.; Murrell, M.T.; Beattie, P. Experimental investigations of the partitioning of $\mathrm{Nb}, \mathrm{Mo}, \mathrm{Ba}, \mathrm{Ce}, \mathrm{Pb}, \mathrm{Ra}, \mathrm{Th}, \mathrm{Pa}$, and $\mathrm{U}$ between immiscible carbonate and silicate liquids. Geochim. Cosmochim. Acta 1995, 59, 1307-1320. [CrossRef]

125. Veksler, I.V.; Dorfman, A.M.; Dulski, P.; Kamenetsky, V.S.; Danyushevsky, L.V.; Jeffries, T.; Dingwell, D.B. Partitioning of elements between silicate melt and immiscible fluoride, chloride, carbonate, phosphate and sulfate melts, with implications to the origin of natrocarbonatite. Geochim. Cosmochim. Acta 2012, 79, $20-40$. [CrossRef]

126. Veksler, I.V.; Petibon, C.; Jenner, G.A.; Dorfman, A.M.; Dingwell, D.B. Trace Element Partitioning in Immiscible Silicate-Carbonate Liquid Systems: An Initial Experimental Study Using a Centrifuge Autoclave. J. Petrol. 1998, 39, 2095-2104. [CrossRef]

127. Barker, D.S. Calculated silica activities in carbonatite liquids. Contrib. Mineral. Petrol. 2001, 141, 704-709. [CrossRef] 
128. Giebel, R.J.; Parsapoor, A.; Walter, B.F.; Braunger, S.; Marks, M.A.W.; Wenzel, T.; Markl, G. Evidence for Magma-Wall Rock Interaction in Carbonatites from the Kaiserstuhl Volcanic Complex (Southwest Germany). J. Petrol. 2019, 60, 1163-1194. [CrossRef]

129. Ray, J.S. Radiogenic Isotopic Ratio Variations in Carbonatites and Associated Alkaline Silicate Rocks: Role of Crustal Assimilation. J. Petrol. 2009, 50, 1955-1971. [CrossRef]

130. Kapustin, Y.L. Mineralogy of Carbonatites; Amerind Publishing Company Pvt. Ltd.: New Dehli, India, 1980.

131. Logvinova, A.M.; Wirth, R.; Tomilenko, A.A.; Afanas'ev, V.P.; Sobolev, N.V. The phase composition of crystal-fluid nanoinclusions in alluvial diamonds in the northeastern Siberian Platform. Russ. Geol. Geophys. 2011, 52, 1286-1297. [CrossRef]

132. Shatskiy, A.; Arefev, A.V.; Podborodnikov, I.V.; Litasov, K.D. Origin of K-rich diamond-forming immiscible melts and $\mathrm{CO}_{2}$ fluid via partial melting of carbonated pelites at a depth of 180-200 km. Gondwana Res. 2019, 75. [CrossRef]

133. Wall, F.; Niku-Paavola, V.N.; Storey, C.; Muller, A.; Jeffries, T. Xenotime-(Y) from carbonatite dykes at Lofdal, Namibia: Unusually low LREE:HREE ratio in carbonatite, and the first dating of xenotime overgrowths on zircon. Can. Mineral. 2008, 46, 861-877. [CrossRef]

134. Chakhmouradian, A.R.; Reguir, E.P.; Zaitsev, A.N.; Couëslan, C.; Xu, C.; Kynický, J.; Mumin, A.H.; Yang, P. Apatite in carbonatitic rocks: Compositional variation, zoning, element partitioning and petrogenetic significance. Lithos 2017, 274-275, 188-213. [CrossRef]

135. Migdisov, A.A.; Williams-Jones, A.E. Hydrothermal transport and deposition of the rare earth elements by fluorine-bearing aqueous liquids. Miner. Depos. 2014, 49, 987-997. [CrossRef]

136. Migdisov, A.; Williams-Jones, A.E.; Brugger, J.; Caporuscio, F.A. Hydrothermal transport, deposition, and fractionation of the REE: Experimental data and thermodynamic calculations. Chem. Geol. 2016, 439, $13-42$. [CrossRef]

137. Nikolenko, A.M.; Redina, A.A.; Doroshkevich, A.G.; Prokopyev, I.R.; Ragozin, A.L.; Vladykin, N.V. The origin of magnetite-apatite rocks of Mushgai-Khudag Complex, South Mongolia: Mineral chemistry and studies of melt and fluid inclusions. Lithos 2018, 320-321, 567-582. [CrossRef]

138. Louvel, M.; Bordage, A.; Testemale, D.; Zhou, L.; Mavrogenes, J. Hydrothermal controls on the genesis of REE deposits: Insights from an in situ XAS study of $\mathrm{Yb}$ solubility and speciation in high temperature fluids $\left(\mathrm{T}<400^{\circ} \mathrm{C}\right)$. Chem. Geol. 2015, 417, 228-237. [CrossRef]

139. Shivaramaiah, R.; Anderko, A.; Riman, R.E.; Navrotsky, A. Thermodynamics of bastnaesite: A major rare earth ore mineral. Am. Mineral. 2016, 101, 1129-1134. [CrossRef]

140. Hsu, L.C. Synthesis and stability of bastnaesites in a part of the system (Ce,La)-F-H-C-O. Mineral. Petrol. 1992, 47, 87-101. [CrossRef]

141. Gysi, A.P.; Williams-Jones, A.E. The thermodynamic properties of bastnäsite-(Ce) and parisite-(Ce). Chem. Geol. 2015, 392, 87-101. [CrossRef]

142. Kutty, T.R.N.; Tareen, J.A.K.; Mohammed, I. Correlation between the stability of carbonates in ternary Ln2O3-H2O-CO2 hydrothermal systems and lanthanide systematics. J. Less Common Met. 1985, 105, 197-209. [CrossRef]

143. Tucker, R.D.; Belkin, H.E.; Schulz, K.J.; Peters, S.G.; Horton, F.; Buttleman, K.; Scott, E.R. A major light rare-earth element (LREE) resource in the Khanneshin carbonatite complex, southern Afghanistan. Econ. Geol. 2012, 107, 197-208. [CrossRef]

144. Samson, I.M.; Wood, S.A.; Finucane, K. Fluid Inclusion Characteristics and Genesis of the Fluorite-Parisite Mineralization in the Snowbird Deposit, Montana. Econ. Geol. 2004, 99, 1727-1744. [CrossRef]

145. Smith, M.P.; Henderson, P.; Campbell, L.S. Fractionation of the REE during hydrothermal processes: Constraints from the Bayan Obo Fe-REE-Nb deposit, Inner Mongolia, China. Geochim. Cosmochim. Acta 2000, 64, 3141-3160. [CrossRef]

146. Borisenko, A.S.; Borovikov, A.A.; Vasyukova, E.A.; Pavlova, G.G.; Ragozin, A.L.; Prokop'ev, I.R.; Vladykin, N.V. Oxidized magmatogene fluids: Metal-bearing capacity and role in ore formation. Russ. Geol. Geophys. 2011, 52, 144-164. [CrossRef]

147. Blount, C.W. Barite solubilities and thermodynamic quantities up to $300{ }^{\circ} \mathrm{C}$ and 1400 bars. Am. Mineral. $1977,62,942-957$. 
148. Benaouda, R.; Devey, C.W.; Badra, L.; Ennaciri, A. Light rare-earth element mineralization in hydrothermal veins related to the Jbel Boho alkaline igneous complex, AntiAtlas/Morocco: The role of fluid-carbonate interactions in the deposition of synchysite-(Ce). J. Geochem. Explor. 2017, 177, 28-44. [CrossRef]

149. Manfredi, T.R.; Bastos Neto, A.C.; Pereira, V.P.; Barbanson, L.; Schuck, C. The parisite-(Ce) mineralization associated with the Fazenda Varela carbonatite (Correia Pinto, SC). Pesqui. Em Geociências 2013, 40, $295-307$. [CrossRef]

150. Nikiforov, A.V.; Bolonin, A.V.; Sugorakova, A.M.; Popov, V.A.; Lykhin, D.A. Carbonatites of Central Tuva: Geological Structure and Mineral and Chemical Composition. Geol. Ore Depos. 2005, 47, 326-345.

151. Nisbet, H.; Migdisov, A.; Xu, H.; Guo, X.; van Hinsberg, V.; Williams-Jones, A.E.; Boukhalfa, H.; Roback, R. An experimental study of the solubility and speciation of thorium in chloride-bearing aqueous solutions at temperatures up to $250{ }^{\circ} \mathrm{C}$. Geochim. Cosmochim. Acta 2018, 239, 363-373. [CrossRef]

152. Al Ani, T.; Sarapää, O. Geochemistry and mineral phases of REE in Jammi carbonatite veins and fenites, southern end of the Sokli complex, NE Finland. Geochem. Explor. Environ. Anal. 2013, 13, 217-224. [CrossRef]

153. Lottermoser, B.G.G. Rare-earth element mineralisation within the Mt. Weld carbonatite laterite, Western Australia. Lithos 1990, 24, 151-167. [CrossRef]

154. Andersen, T. A model for the evolution of hematite carbonatite, based on whole-rock major and trace element data from the Fen complex, southeast Norway. Appl. Geochem. 1987, 2, 163-180. [CrossRef]

(C) 2020 by the authors. Licensee MDPI, Basel, Switzerland. This article is an open access article distributed under the terms and conditions of the Creative Commons Attribution (CC BY) license (http://creativecommons.org/licenses/by/4.0/). 